\title{
Mechanisms of tRNA-derived fragments and tRNA halves in cancer treatment resistance
}

\author{
Yue Zhang ${ }^{\dagger}$, Huizhu Qian ${ }^{\dagger}$, Jing $\mathrm{He}^{*}$ and Wen Gao ${ }^{*}$
}

\begin{abstract}
The tRNA-derived fragments (tRFs) and tRNA halves (tiRNAs) are newly discovered noncoding RNAs in recent years. They are derived from specific cleavage of mature and pre-tRNAs and expressed in various cancers. They enhance cell proliferation and metastasis or inhibit cancer progression. Many studies have investigated their roles in the diagnosis, progression, metastasis, and prognosis of various cancers, but the mechanisms through which they are involved in resistance to cancer treatment are unclear. This review outlines the classification of tRFs and tiRNAs and their mechanisms in cancer drug resistance, thus providing new ideas for cancer treatment.
\end{abstract}

Keywords: tRNA-derived fragments, tRNA halves, Cancer, Drug resistance, Biomarker

\section{Background}

Transfer RNAs (tRNAs) have long been regarded as classic noncoding RNAs and are involved in protein translation [1]. Recently, many researchers have discovered new noncoding RNAs that are derived from specific cleavage of pre- and mature tRNA. Noncoding RNAs derived from tRNA are grouped into two categories: tRNA-derived fragments (tRFs) and tRNA halves (tiRNAs) [1]. The tRFs originate from mature or pre-tRNAs, and they are approximately 14-30 nucleotides (nt) in length. tiRNAs are 29-50 nt in length and originate from specific cleavage of mature tRNA anticodon loop under stress $[2,3]$. The tRFs are conservative and widespread in nature [4]. They were initially discovered as random tRNA degradation fragments and later found to be generated by conservative and specific tRNA cleavage [5]. The tRFs are associated with cancer, inherited metabolic diseases, viral infections, and neurodegenerative diseases [6]. Here, we introduce the classification of tRFs and

\footnotetext{
* Correspondence: gaowen@jsph.org.cn; hejinggy@163.com

†Y Yue Zhang and Huizhu Qian contributed equally to this work. Department of Oncology, The First Affiliated Hospital of Nanjing Medical University, 300 Guangzhou Road, Nanjing 210029, China
}

tiRNAs, discuss their roles in cancers, summarize their mechanisms of drug resistance in cancer treatment, and describe techniques for studying tRFs and tiRNAs.

Classification of tRFs and tiRNAs and their roles in cancers The tRFs include tRF-1, tRF-2, tRF-3, tRF-5, and i-tRF [5] (Fig. 1). The tRF-1 is produced by cleaving 3 ' pretRNA by RNase $\mathrm{Z}$ or its cytoplasmic ribonuclease $\mathrm{Z} 2$ (ELAC2) in the T $\psi \mathrm{C}$ loop [7]. tRF-1 has carcinogenic or anticancer effects in the occurrence and development of cancers [5]. tRF-2 is derived from the decomposition of anticodon loops of tRNAs under hypoxic condition [8]. Angiogenin and Dicer cleave the T-loop of 3 '-ends of mature tRNA to produce tRF-3. tRF-3 includes tRF-3a and tRF-3b $[7,8]$. Dicer cleaves the D-loop of tRNA to produce tRF-5. tRF- 5 includes tRF- $5 a$, tRF- $5 b$, and tRF$5 \mathrm{c}$ [5]. The tRF-5 is mostly located in the nucleus, whereas tRF-3 and tRF-1 mainly occur in the cytoplasm [8]. The i-tRF spans the anticodon loop and is derived from mature tRNA [9]. The tiRNAs are produced by cleaving the anticodon loop of mature tRNA by angiogenin under stress conditions. There are two types of tiRNAs: $5^{\prime}$ tRNA half (tiRNA-5) and 3'-tRNA half (tiRNA-3) [10].

(c) The Author(s). 2020 Open Access This article is licensed under a Creative Commons Attribution 4.0 International License, which permits use, sharing, adaptation, distribution and reproduction in any medium or format, as long as you give appropriate credit to the original author(s) and the source, provide a link to the Creative Commons licence, and indicate if changes were made. The images or other third party material in this article are included in the article's Creative Commons licence, unless indicated otherwise in a credit line to the material. If material is not included in the article's Creative Commons licence and your intended use is not permitted by statutory regulation or exceeds the permitted use, you will need to obtain permission directly from the copyright holder. To view a copy of this licence, visit http://creativecommons.org/licenses/by/4.0/ The Creative Commons Public Domain Dedication waiver (http://creativecommons.org/publicdomain/zero/1.0/) applies to the data made available in this article, unless otherwise stated in a credit line to the data. 


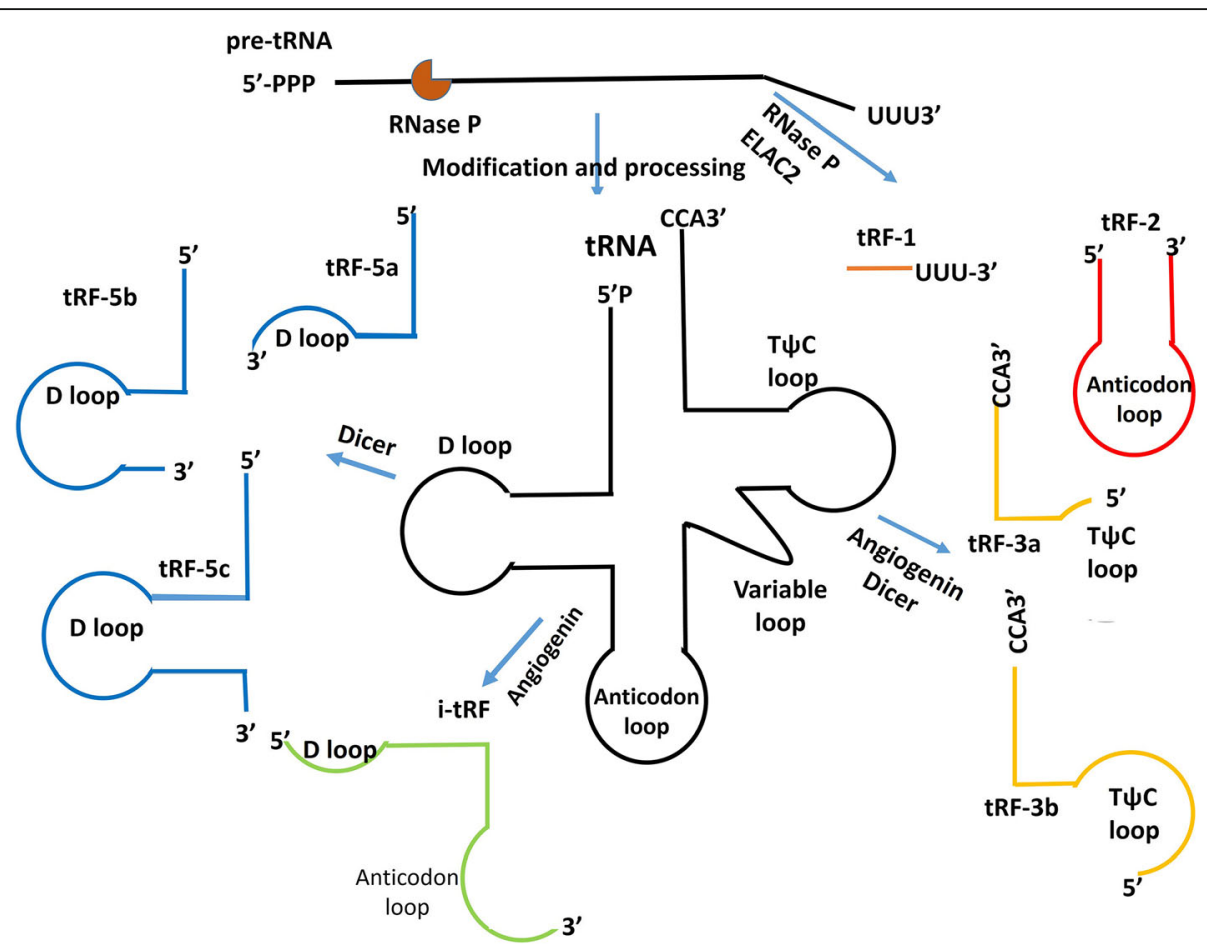

Fig. 1 Classification of tRFs. TRFs include tRF-1, tRF-2, tRF-3, tRF-5, and i-tRF. tRF-1 is generated from the $3^{\prime}$-end of pre-tRNA. tRF-2 is a tRNA fragment containing an anti-codon loop generated by an unknown cleavage method. tRF-3 and tRF-5 are derived from the $3^{\prime}$ - and $5^{\prime}$-ends of mature tRNAs, respectively. i-tRF originates from the internal region of mature tRNA

Nutritional deficiency, hypoxia, heat shock, and oxidative stress can stimulate angiogenin activity and increase tRNA cleavage [11].

The tRFs and tiRNAs regulate ribosome and protein biogenesis; DNA damage response; gene expression; RNA interference; immune mediation; and cell proliferation, apoptosis, and migration $[4,8,57]$. They are expressed and dysregulated in various cancers [58] (Table 1). The heterogeneity and stability of tRFs make it suitable biomarkers for cancer diagnosis and prognosis [19]. Acquired treatment resistance is the main dilemma of cancer treatment [59]. Many studies have systematically discussed the roles of tRFs and tiRNAs in the diagnosis, progression, metastasis, and prognosis of various cancers $[1,5]$, but few studies have investigated their roles in resistance to cancer treatment. Herein, we summarize their mechanisms in cancer drug resistance (Table 2).

Mechanisms of tRFs and tiRNAs in cancer drug resistance Drug resistance occurs when the therapeutic efficacy of a drug decreases. Drug resistance is an obstacle to cancer treatment and patient survival. The tRFs and tiRNAs can replace eukaryotic translation initiation factor 4G (eIF4G) that binds to mRNA, thus inhibiting protein translation [41]. The downregulation of eIF4G increases doxorubicin sensitivity by inhibiting the expression of adenosine triphosphate-binding cassette $(\mathrm{ABC})$ transporter in breast cancer cells [60]. ABC transporter can efflux anticancer drugs across cell membranes, which is associated with drug resistance of many solid tumors $[13,61]$. The inhibition of eIF4F complex, including eIF4E, eIF4G, and eIF4A, enhances the sensitivity of various anticancer drugs, such as cisplatin sensitivity in non-small cell lung cancer (NSCLC) [62], trastuzumab and tamoxifen sensitivity in breast cancer [63, 64], and enzalutamide and bicalutamide sensitivity in castration-resistant prostate cancer (CRPA) [65]. In addition, tRFs and tiRNAs can promote the assembly of stress granules (SGs) under stress conditions [40]. SGs allow cells to recruit and protect mRNAs during stress [66]. SGs are related to drug resistance $[67,68]$. The elimination of SG sequestration is associated with acquired drug resistance [69]. The assembly of SGs makes glioblastoma resistant to bortezomib, and thus, the drug is unable to inhibit angiogenesis [66].

\section{Mechanisms of breast cancer resistance related to tRFs and tiRNAs}

Breast cancer ranks second among the causes of female cancer-related deaths [70]. Chemotherapy resistance causes high mortality of patients with breast cancer [71]. The exact mechanisms of chemoresistance have not yet been fully elucidated. Herein, we summarize the mechanisms by which tRFs play a role in resistance to breast cancer therapy. 
Table 1 Roles of tRNA-derived fragments and tRNA halves in cancers

\begin{tabular}{|c|c|c|c|c|}
\hline Cancer & tRFs and tiRNAs & Type & Findings & References \\
\hline \multirow[t]{14}{*}{ breast cancer } & $\begin{array}{l}\text { tRF-30-JZOYJE22RR33 } \\
\text { tRF-27-ZDXPHO53KSN }\end{array}$ & tRF & Independent predictors of PFS in HER-2-positive breast cancer & [12] \\
\hline & $\begin{array}{l}\text { tRF-0009 } \\
\text { tDR-7336 }\end{array}$ & tRF & Facilitate doxorubicin resistance & {$[13,14]$} \\
\hline & tRF3E & tiRNA-3 & tumor suppressor & [15] \\
\hline & tDR-7816 & tRF & diagnostic biomarker of early non-TNBC & [16] \\
\hline & ts-112 & tRF & $\begin{array}{l}\text { ts-112 inhibition reduces the proliferative capacity of aggressive } \\
\text { breast cancer cells. }\end{array}$ & [17] \\
\hline & $5^{\prime}$-tiRNA ${ }^{\text {Val }}$ & tiRNA-5 & $\begin{array}{l}\text { 5'-tiRNAVal overexpression significantly suppresses } \\
\text { breast tumor cell proliferation, } \\
\text { migration and invasion. }\end{array}$ & [18] \\
\hline & tRF-32-Q99P9P9NH57SJ & tiRNA-5 & tumour stage and lymph node metastasis & [19] \\
\hline & $\begin{array}{l}\text { SHOT-RNAAsp-GUC } \\
\text { SHOT-RNAHis-GUG } \\
\text { SHOT-RNALys-CUU }\end{array}$ & tiRNA & SHOT-RNAs enhance cell proliferation. & [20] \\
\hline & tDR-000620 & tRF & aggressive phenotype of breast cancer stem cells & [21] \\
\hline & $5^{\prime}$-tiRNA ${ }^{\text {Asp }}, 5^{\prime}$-tiRNA ${ }^{\text {His }}$ & tiRNA-5 & elevate in breast cancer & [22] \\
\hline & $\begin{array}{l}\text { tRF } \\
\text { tRF }^{\text {Asp-YT-GTC }} \\
\text { tRF }^{\text {Gly-TCC }}\end{array}$ & i-tRF & suppress cell proliferation and cancer metastasis & [23] \\
\hline & $\mathrm{tRF}^{\mathrm{Ser}-\mathrm{GCT}}$ & i-tRF & Unknown & [24] \\
\hline & $\begin{array}{l}\text { tRF-2 derived from } \\
\text { tRNA Glu, tRNA }{ }^{\text {Asp }} \\
\text { tRNA }{ }^{\text {Gly }}, \text { and tRNA }\end{array}$ & tRF-2 & $\begin{array}{l}\text { Bind to YBX1 by displacing } 3^{\prime}-\text { UTR, thus suppressing cancer cell } \\
\text { growth and metastasis }\end{array}$ & [25] \\
\hline & ts- 46 , ts-47 & tRF-1 & $\begin{array}{l}\text { ts- } 46 \text { and ts- } 47 \text { are upregulated by PIK3CA and KRAS mutations, } \\
\text { respectively. These two mutations are involved in the resistance } \\
\text { of breast cancer cells to lapatinib. }\end{array}$ & [26] \\
\hline \multirow[t]{3}{*}{ lung cancer } & $\begin{array}{l}\text { ts-101 } \\
\text { ts-53 }\end{array}$ & tRF-1 & $\begin{array}{l}\text { Associate with PiwiL2, an essential protein involved in silencing } \\
\text { of transposons }\end{array}$ & [25] \\
\hline & $\begin{array}{l}\text { ts-46 } \\
\text { ts-47 }\end{array}$ & tRF-1 & $\begin{array}{l}\text { have inhibitory effect on the ability of lung cancer cells to form } \\
\text { colonies }\end{array}$ & [25] \\
\hline & $\mathrm{tRF}^{\mathrm{Leu}-\mathrm{CAG}}$ & tiRNA-5 & Promote cell proliferation and G0/G1 cell cycle progression & {$[27]$} \\
\hline pancreatic cancer & $\begin{array}{l}\text { AS-tDR-000064 } \\
\text { AS-tDR-000069 } \\
\text { AS-tDR-000102 } \\
\text { AS-tDR-001391 }\end{array}$ & tiRNA-5 & diagnostic and therapeutic biomarkers & [28] \\
\hline \multirow[t]{5}{*}{ colorectal cancer } & tRF/miR-1280 & $\begin{array}{l}\text { tRNALeu and } \\
\text { pre-miRNA }\end{array}$ & suppress colorectal cancer growth and metastasis & [29] \\
\hline & tiRNA-Tyr-GTA & tiRNA-5 & $\begin{array}{l}\text { Targets of tiRNA-Tyr-GTA are mainly enriched in the PPAR } \\
\text { signaling pathway. }\end{array}$ & [30] \\
\hline & tRF-GIn-CTG & tRF-5c & $\begin{array}{l}\text { Negative regulation of c-Jun N-terminal kinase (JNK) cascade is } \\
\text { enriched in tRF-GIn-CTG. Inhibition of JNK cascade can reduce } \\
\text { the migration potential of colon cancer cells in vitro. }\end{array}$ & {$[30]$} \\
\hline & tRF-Leu-TAG & tRF-5a & $\begin{array}{l}\text { Function of mesenchymal-to-epithelial transition is enriched in } \\
\text { tRF-Leu-TAG. }\end{array}$ & [30] \\
\hline & $\begin{array}{l}\text { 5'-tRF-Lys }{ }^{T T} \\
\text { 5'-tRF-Val } \\
\text { 5'-tRF-Glu } \\
\text { 'TC' } \\
\text { 5'-tRF-Pro }\end{array}$ & tRF-5 & $\begin{array}{l}\text { Associate with chemotherapy } \\
\text { treatment outcomes }\end{array}$ & [26] \\
\hline \multirow[t]{3}{*}{ prostate cancer } & tRF-1001 & tRF-1 & TRF-1001 is required for cell proliferation. & [31] \\
\hline & $\begin{array}{l}\text { tRNA } A^{\text {Lys-CTT }} \\
\text { tRNA }\end{array}$ & tRF & $\begin{array}{l}\text { The ratio of tRFs derived from tRNA } A^{\text {Lys-CT }} \text { and tRNA } \\
\text { good indicator of progression-free survival. }\end{array}$ & [32] \\
\hline & $\begin{array}{l}\text { tRF-544 } \\
\text { tRF-315 }\end{array}$ & $\begin{array}{l}\text { tRF-5 } \\
\text { tRF-3 }\end{array}$ & High expression ratio of tRF-315/tRF-544 predicts poor PFS. & [32] \\
\hline
\end{tabular}


Table 1 Roles of tRNA-derived fragments and tRNA halves in cancers (Continued)

\begin{tabular}{|c|c|c|c|c|}
\hline Cancer & tRFs and tiRNAs & Type & Findings & References \\
\hline & $\begin{array}{l}\text { SHOT-RNAAsp-GUC } \\
\text { SHOT-RNAHIs-GUG } \\
\text { SHOT-RNALys-CUU }\end{array}$ & tiRNA & SHOT-RNAs enhance cell proliferation. & [20] \\
\hline liver cancer & $\mathrm{tRF}^{\mathrm{Ser}}$ & tRF-3 & Cleavage of tRNAs during stress & [33] \\
\hline cervical cancer & $\mathrm{tRF}^{\mathrm{Gln}}$ & tRF-5 & inhibit the process of protein translation & [34] \\
\hline \multirow{2}{*}{$\begin{array}{l}\text { clear cell renal cell } \\
\text { carcinoma }\end{array}$} & 5'-tRNA4-Val-AAC & tiRNA-5 & advanced stage and grade & [35] \\
\hline & $\begin{array}{l}\text { 5'-tiRNA-Arg-CCT, } \\
\text { 5'-tiRNA-Glu-CTC, } \\
\text { 5'-tiRNA-Leu-CAG, } \\
\text { 5'-tiRNA-Lys-TTT }\end{array}$ & tiRNA-5 & Potential tumor suppressors & [36] \\
\hline \multirow[t]{2}{*}{ B cell lymphoma } & CU1276 (tRF-3018) & tRF-3 & $\begin{array}{l}\text { CU1276 associates with argonaute proteins, represses } \\
\text { endogenous RPA1, suppresses proliferation, and modulates } \\
\text { molecular response to DNA damage. Loss of CU1276 } \\
\text { expression may confer a growth advantage to malignant cells. }\end{array}$ & {$[37]$} \\
\hline & $\begin{array}{l}\text { tRFHis-GTG } \\
\text { tRFLeu-CAG }\end{array}$ & tRF-3 & $\begin{array}{l}\text { associate with Ago } 2 \text { and downregulate target genes by } \\
\text { transcript cleavage }\end{array}$ & [38] \\
\hline \multirow[t]{2}{*}{ ovarian cancer } & tRF5-Glu & tRF-5 & $\begin{array}{l}\text { Increased tRF5-Glu inhibits the proliferation of ovarian } \\
\text { cancer cells. }\end{array}$ & [39] \\
\hline & tRF-03357 & tRF-5 & tRF-03357 promotes cell proliferation, migration, and invasion. & [40] \\
\hline \multirow[t]{2}{*}{ osteosarcoma } & $\begin{array}{l}\text { tiRNA } A^{\text {Ala }} \\
\text { tiRNA } A^{\text {Cys }}\end{array}$ & tiRNA-5 & $\begin{array}{l}\text { Inhibit protein synthesis and trigger the phospho-elF2a-in } \\
\text { dependent assembly of stress granules }\end{array}$ & [41] \\
\hline & $\mathrm{tRF}^{\mathrm{Val}}$ & tRF-5 & tRF ${ }^{\mathrm{Val}}$ induces the assembly of cytoprotective stress granules. & [41] \\
\hline \multirow[t]{5}{*}{$\begin{array}{l}\text { chronic lymphocytic } \\
\text { leukemia }\end{array}$} & ts-101, ts-53 & tRF-1 & $\begin{array}{l}\text { ts-53 targets the } 3^{\prime}-U T R \text { of TCL1, a key oncogene in the } \\
\text { development of aggressive CLL. ts- } 101 \text { and ts- } 53 \text { associate with } \\
\text { PiwiL2, an essential protein involved in silencing of transposons. }\end{array}$ & {$[42]$} \\
\hline & ts -46, ts -47 & tRF-1 & potential tumor suppressors & [43] \\
\hline & i-tRF-GlyCCC & $\mathrm{i}-\mathrm{tRF}$ & predict poor overall survival & [44] \\
\hline & i-tRF-GlyGCC & $\mathrm{i}-\mathrm{tRF}$ & prognostic biomarker & {$[45]$} \\
\hline & ts $-43, \mathrm{ts}-44$ & tRF-5 & tumor suppressors & [46] \\
\hline $\begin{array}{l}\text { head and neck } \\
\text { squamous cell } \\
\text { carcinoma }\end{array}$ & $\begin{array}{l}5^{\prime}-\text { tiRNA } A^{\text {Ala }} \\
5^{\prime}-\text { tiRNA } A^{\text {Cys }} \\
5^{\prime} \text {-tiRNA }\end{array}$ & tiRNA-5 & significantly increase & [47] \\
\hline uveal melanoma & $\begin{array}{l}\text { tRF-22-BP4MJYSZH } \\
\text { tRF-21-45DBNIB9B }\end{array}$ & i-tRF & associated with metastasis and patient survival & [48] \\
\hline gastric cancer & tRF-3019a & tRF & $\begin{array}{l}\text { tRF-3019a overexpression enhances gastric cancer cell } \\
\text { proliferation, migration, and invasion }\end{array}$ & [49] \\
\hline $\begin{array}{l}\text { testicular germ cell } \\
\text { tumor }\end{array}$ & tRF (20 nt) & tRF & $\begin{array}{l}\text { Associated with cancer } \\
\text { development and progression }\end{array}$ & [26] \\
\hline
\end{tabular}

Resistance is common in triple-negative breast cancer (TNBC) [13]. Hypoxia is a characteristic of the tumor microenvironment and is related to tumor aggressiveness, metastatic potential, and chemoresistance [72]. Hypoxia can also induce tRFs. Hypoxia promotes chemoresistance to TNBC treatment in various ways. It can hinder drug penetration, affect cytotoxicity of drugs, induce breast cancer stem cell (CSC) phenotype, and regulate tumor immunity [72]. However, few studies have linked hypoxiainduced tRFs to drug resistance. Cui et al. studied the role of hypoxia-induced tRFs in doxorubicin resistance during TNBC treatment and found that tDR-0009 and tDR-7336 were significantly upregulated, while tDR-0124 and tDR-
11,898 were downregulated. Gene ontology (GO) analysis indicates that tDR-0009 and tDR-7336 can maintain cell response to interleukin (IL)-6 [13]. IL-6 participates in multidrug resistance by activating the Janus kinase (JAK)/Signal transducer and activator of transcription 3 (STAT3), phosphoinositide 3-kinase (PI3K)/Protein Kinase $\mathrm{B}$ (Akt), and Ras-Mitogen-activated protein kinase (MAPK) pathways [50]. STAT3 mediates TNBC resistance through the NF- $\mathrm{kB}$ pathway, Bcl-2-associated $\mathrm{x}$ protein (Bax), and the TNFRSF1A gene [59, 73, 74]. In TNBC immunotherapy, STAT3 enhances PD-L1 expression, thus weakening the response to anti-PD-L1 therapy [75]. Furthermore, IL6 can increase HIF- $1 \alpha$ expression by activating STAT3. 
Table 2 Roles of tRNA-derived fragments and tRNA halves in cancer drug resistance

\begin{tabular}{|c|c|c|c|}
\hline Cancer & tRFs and tiRNAs & Findings & References \\
\hline \multirow[t]{8}{*}{ breast cancer } & $\begin{array}{l}\text { tDR-0009 } \\
\text { tDR-7336 }\end{array}$ & $\begin{array}{l}\text { tDR-0009 and tDR-7336 can maintain cell response to IL-6, } \\
\text { which participates in multidrug resistance by activating the } \\
\text { JAK/STAT3, PI3KAAkt, and Ras-MAPK pathways. }\end{array}$ & {$[13,50]$} \\
\hline & $\begin{array}{l}\text { tDR-0124 } \\
\text { tDR-11,898 }\end{array}$ & tDR-0124 and tDR-11,898 are involved in chemoresistance & [13] \\
\hline & $\begin{array}{l}\text { tRF-30-JZOYJE22RR33 } \\
\text { tRF-27-ZDXPHO53KSN }\end{array}$ & trastuzumab resistance & [12] \\
\hline & tDR-5334 & tamoxifen resistance & {$[16,51]$} \\
\hline & tDR-4733 & $\begin{array}{l}\text { tDR-4733 mediates acquired resistance to HER2 inhibitors } \\
\text { through the PI3K/AKT/mTOR signaling pathway. }\end{array}$ & [52] \\
\hline & $5^{\prime}$-tiRNA $A^{\text {Val }}$ & $\begin{array}{l}5^{\prime} \text {-tiRNA }{ }^{\text {Val }} \text { can directly bind to FZD3 and inhibit the } \\
\text { FZD3-mediated Wnt/ } \beta \text {-catenin pathway, which is related } \\
\text { to tamoxifen and doxorubicin resistance. }\end{array}$ & [18] \\
\hline & $\begin{array}{l}\text { tRF-2 derived from } \\
\text { tRNA }{ }^{\text {Glu }} \text {, tRNA }{ }^{\text {Asp }} \\
\text { tRNA }^{\text {Gly }} \text { and tRNA }\end{array}$ & $\begin{array}{l}\text { tRFs increase chemosensitivity of various tumors by } \\
\text { replacing 3'-UTR from YBX1. }\end{array}$ & {$[23,53]$} \\
\hline & ts-46, ts-47 & $\begin{array}{l}\text { ts- } 46 \text { and ts- } 47 \text { are upregulated by PIK3CA and KRAS } \\
\text { mutations, respectively. These two mutations are involved } \\
\text { in the resistance of breast cancer cells to lapatinib. }\end{array}$ & [26] \\
\hline \multirow[t]{2}{*}{ lung cancer } & tRF-Leu-CAG & $\begin{array}{l}\text { tRF-Leu-CAG may be related to AURKA. AURKA } \\
\text { overexpression induces gefitinib and cisplatin resistance. }\end{array}$ & {$[27,54,55]$} \\
\hline & ts-101, ts-46, ts-47 & Mediate multidrug resistance & [25] \\
\hline pancreatic cancer & tRF-1391 & $\begin{array}{l}\text { Target genes of tRF-1391 are mainly concentrated in the } \\
\text { PI3K/Akt pathway, which is related to doxorubicin } \\
\text { resistance. }\end{array}$ & {$[28,56]$} \\
\hline \multirow[t]{2}{*}{ colorectal cancer } & tRF/miR-1280 & $\begin{array}{l}\text { tRF/miR-1280 binds to 3'-UTR of JAG2, thus inhibiting } \\
\text { Notch/Gata and miR-200b signaling. JAG2, Notch, Gata, } \\
\text { and miR-200b are related to drug } \\
\text { resistance. }\end{array}$ & [29] \\
\hline & $\begin{array}{l}\text { tiRNA-Tyr-GTA } \\
\text { tRF-GIn-CTG } \\
\text { tRF-Leu-TAG }\end{array}$ & chemoresistance & [30] \\
\hline ovarian cancer & $\begin{array}{l}\text { tRF-03357 } \\
\text { tRF-03358 }\end{array}$ & $\begin{array}{l}\text { tRFs are involved in the MAPK, FoxO, and Wnt pathways } \\
\text { and affect sensitivity to cisplatin. }\end{array}$ & [40] \\
\hline chronic lymphocytic leukemia & ts -101, ts -53, ts -46, ts -47 & unclear & [25] \\
\hline
\end{tabular}

HIF-1 $\alpha$ mediates the expression of P-glycoprotein (P-gp) and Multidrug Resistance Protein 1 (MRP1) [50]. In conclusion, tDR-0009 and tDR-7336 may participate in the drug resistance of TNBC by regulating the activation of STAT3 phosphorylation [13]. Target genes of tDR-0124 are related to cell cycle regulation, while target genes of tDR-11,898 participate in the regulation of RNA polymerase II promoter transcription and RNA biosynthesis, which are involved in chemoresistance [13]. Insulin-like growth factor 2 (IGF2) is one of the proteins that interact most frequently with the target genes of tDR-11,898 [13]. The binding of IGF2 to insulin-like growth factor receptor 1 (IGF1R)/insulin receptor A (IR-A) activates the downstream signaling cascade and eventually stimulates cell growth and expression of $\mathrm{ABC}$ transporters [76, 77]. These data illustrate that tRF-0009, tDR-7336, tDR-0124 and tDR-11,898 may play a role in hypoxia-induced chemoresistance through multiple mechanisms (Fig. 2).
Sun et al. investigated tRFs related to trastuzumab resistance in human epidermal growth factor receptor-2 (HER2)-positive breast cancer [12]. tRF-30-JZOYJE22 RR33 and tRF-27-ZDXPHO53KSN were overexpressed in trastuzumab-resistant patients. These two tRFs may lead to trastuzumab resistance by regulating the expression product of target genes or competing with mRNAs for binding to RNA-binding proteins [12]. They are intervention targets for predicting trastuzumab resistance in the treatment of breast cancer.

Huang et al. reported that tDR-7816, tDR-5334, and tDR-4733 were downregulated in nontriple-negative breast cancer patients compared to healthy people [16]. GO and KEGG pathway analyses indicate that the target genes of tDR-5334 are involved in the glycosylation process. Abnormal glycosylation is involved in the activation of oncogenic signaling pathways and induces cancer metastasis [16]. N-glycosylation of $\beta 1$-integrin in epithelial- 


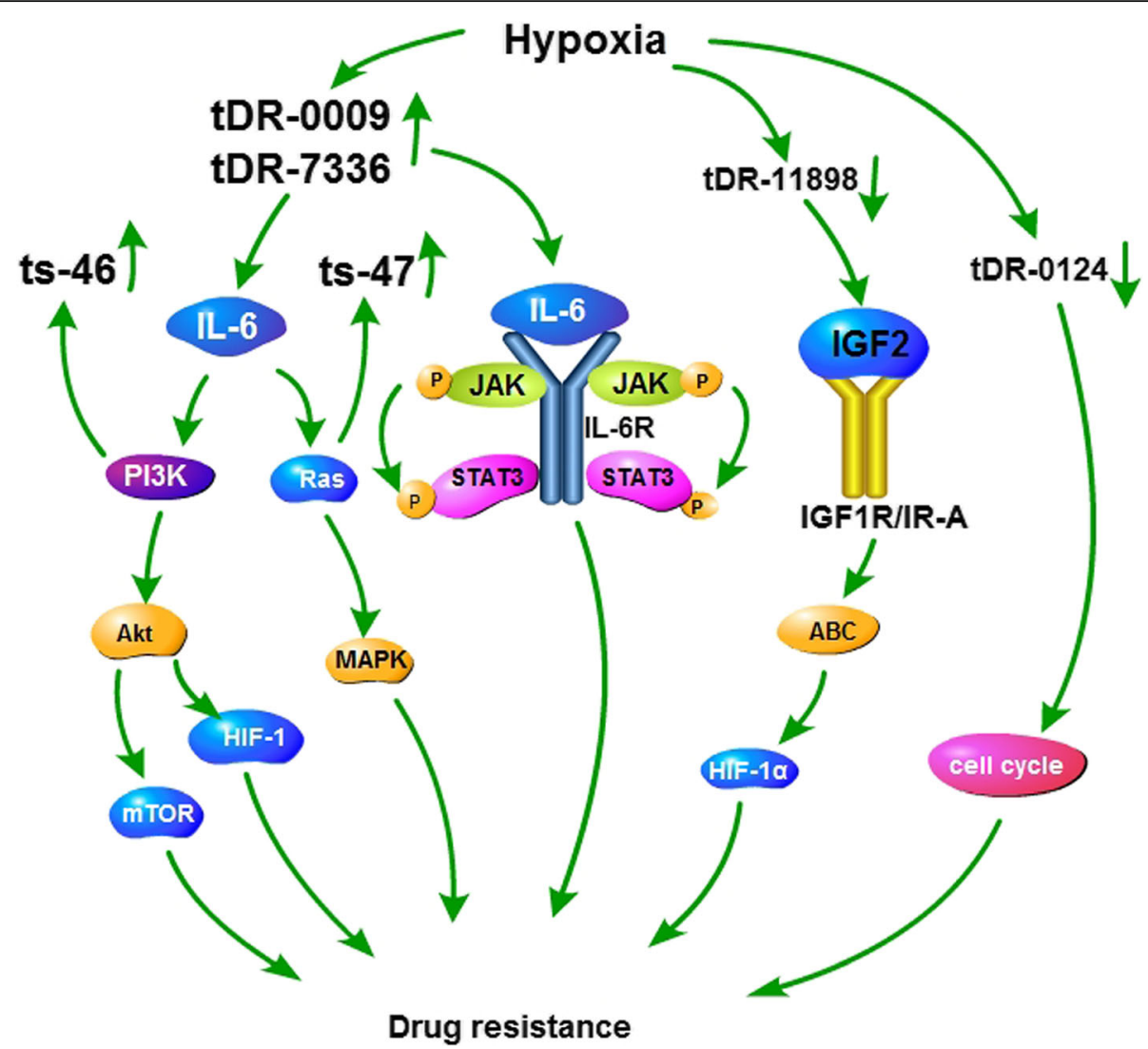

Fig. 2 Mechanisms of tDR-0009, tDR-7336, tDR-0124, tDR-11,898, ts46, and ts47 in breast cancer resistance. tDR-0009 and tDR-7336 are upregulated, while tDR-0124 and tDR-11,898 are downregulated in resistance of triple-negative breast cancer to doxorubicin. tDR-0009 and tDR7336 can maintain cell response to IL-6. IL-6 participates in multidrug resistance by activating the JAK/STAT3, PI3K/Akt/mTOR, and Ras-MAPK pathways. AKT can induce HIF-1 and mediate drug resistance. ABC transporter plays an important role in breast cancer resistance. Target genes of tDR-0124 are related to cell cycle regulation, which are involved in chemoresistance. IGF2 is one of the proteins that interact most frequently with the target genes of tDR-11,898. The binding of IGF2 to IGF1R/IR-A activates the downstream signaling cascade and eventually stimulates the expression of ABC transporters. ts-46 and ts-47 are upregulated by PIK3CA and KRAS mutations, respectively. Both mutations are related to the development of breast cancer chemoresistance

to-mesenchymal transition (EMT) partly explained the reason for trastuzumab resistance in HER2-positive breast cancer [78]. Glycosylation is a non-negligible multidrug resistance mechanism. The analysis of target genes of tDR5334 revealed that STAT1 is the central protein in the protein-protein interaction (PPI) network [16]. STAT1 regulates ER $\alpha$ transcription and ER $\alpha$ signaling and is associated with tamoxifen resistance [51]. The analysis of target genes of tDR-4733 showed that tDR-4733 is involved in lipid metabolism and cell cycle regulation [16]. Changes in lipid metabolism mediate the development of acquired resistance to HER2 inhibitors through the PI3K/AKT/mTOR signaling [52]. The central protein cyclin B1 is a key part of cell cycle that causes cells to undergo mitosis [16]. Sabbaghi et al. reported that trastuzumab-emtansine-induced cyclin B1 deficiency mediates drug resistance in HER2-positive breast cancer [79]. In addition, hypoxia can inhibit the expression of cyclin B1 in MCF-7 cells. Overexpression of cyclin B1 enhances paclitaxel sensitivity. Therefore, under hypoxic conditions, downregulated cyclin B1 can further promote paclitaxel resistance [80].

Mo et al. reported that the expression of $5^{\prime}$ fragment of tRNA-Val-CAC $\left(5^{\prime}\right.$-tiRNA $\left.{ }^{\mathrm{Val}}\right)$ was reduced in breast cancer [18]. The $5^{\prime}$-tiRNA ${ }^{\mathrm{Val}}$ regulated cell proliferation, migration, and invasion in breast cancer. Frizzled homo$\log 3$ (FZD3), $\beta$-catenin, c-myc, and cyclin D1 were downregulated, while Adenomatous Polyposis Coli (APC) was upregulated in cells overexpressing $5^{\prime}$-tiRNA ${ }^{\text {Val }}$. The FZD3 protein is mapped to chromosome 8p21, a major component of the Wnt signaling pathway, which is involved in regulating early neural development [81]. The $5^{\prime}$-tiRNA ${ }^{\text {Val }}$ can directly bind to FZD3 and inhibit FZD3-mediated Wnt/ $\beta$-catenin pathway [18], which is related to tamoxifen and doxorubicin resistance $[82,83]$. In addition, the downregulation of FZD3 significantly reduces the expression of cyclin D1 and c-myc [18]. Cmyc can confer chemoresistance in breast cancer cells $[84,85]$. Seventy percent of patients with sporadic breast 
cancer lose APC because of mutation or hypermethylation $[86,87]$. The loss of APC results in resistance to doxorubicin and cisplatin by STAT3, EGFR, NOTCH, and Hedgehog signaling [88-90]. The STAT3 signaling pathway mainly plays a role in APC-mediated resistance to doxorubicin, but not to cisplatin [71]. To summarize, we speculate that $5^{\prime}$-tiRNA ${ }^{\mathrm{Val}}$ plays a role in breast cancer chemoresistance through FZD3, $\beta$-catenin, c-myc, and APC.

In breast cancer, tRNAGlu, tRNAAsp, tRNAGly, and tRNATyr are exposed to stress and are enzymatically cleaved to produce tRFs [23]. The induction of these tRFs inhibits the stability of oncogenic transcripts by replacing 3 '-UTR from the RNA-binding protein Y Box-Binding Protein 1 (YBX1), thereby inhibiting metastasis [23]. YBX1 is a versatile RNA-binding protein with a variety of interacting partners. Genetic inactivation of YBX1 leads to embryonic lethality [91]. YBX1 is overexpressed in multiple cancers [53] and enhances chemoresistance in melanoma [92], embryonal rhabdomyosarcoma [93], NSCLC [94], prostate cancer [95], gastric cancer [96], breast cancer [97], neuroblastoma [53], hepatocellular carcinoma [98], ovarian carcinoma [99], bladder cancer [100], diffuse large B-cell lymphoma [101], prostate cancer [102], chordomas [103], and esophageal squamous cell carcinoma (ESCC) [104]. YBX1 promotes cancer chemoresistance by upregulating $\mathrm{ABC}$ transporters related to multidrug resistance $[53,94$, $97,104,105]$. Overexpression of YBX1 confers resistance to mitoxantrone by cell adhesion mechanisms in diffuse large B-cell lymphoma [101]. In addition, YBX1 also transcriptionally activates the expression of drug resistance-related genes MVP/LRP, TOP2A, CD44, CD49f, BCL2, and MYC [106]. In summary, tRFs may increase chemosensitivity of various tumors by replacing 3 '-UTR from YBX1.

In addition, Corce $\mathrm{M}$ et al. reported that ts- 46 and ts47 were upregulated by PIK3CA and KRAS mutations, respectively. These two mutations were involved in the resistance of breast cancer cells to lapatinib [26].

Chemoresistance causes high mortality of patients with breast cancer. The mechanisms by which tRFs induce chemoresistance in breast cancer can be applied to develop therapies to overcome drug resistance and prolong survival.

\section{Mechanisms of lung cancer resistance related to tRFs and tiRNAs}

Lung cancer has the highest mortality rate among all tumors. The 5-year survival rate is 19\% [70]. Among all lung cancers, NSCLC accounts for more than 80\% [107]. Epidermal growth factor receptor tyrosine kinase inhibitors (EGFR-TKIs) usually produce incomplete response within 9-12 months of treatment and then develop resistance. Shao et al. found that tRF-Leu-CAG was significantly upregulated in advanced NSCLC and promoted cell proliferation. Knockdown of tRF-Leu-CAG downregulated Aurora-A kinase (AURKA) in $\mathrm{H} 1299$ cells, indicating that tRF-Leu-CAG may be related to AURKA [27]. AURKA is a member of the Aurora kinase family of serine/threonine kinases and is involved in cell mitosis [108]. AURKA phosphorylates p53 at Ser315, resulting in its ubiquitination by Mdm2 and proteolysis [109]. In HCC827 cells, AURKA overexpression induced gefitinib resistance by downregulating the p53 signaling pathway [54]. The combination of EGFR-TKIs and AURKA inhibitors can suppress resistance [110]. Furthermore, in vitro data showed that AURKA overexpression was related to cisplatin resistance [55]. In addition to targeted therapy, the AURKA/ NF- $\mathrm{KB}$ pathway is related to radio-resistance in docetaxelresistant lung adenocarcinoma [111]. These data indicate that tRF-Leu-CAG may become a potential therapeutic target to reverse drug resistance in NSCLC. (Fig. 3).

Balatti et al. found that ts-101, ts-53, ts- 46 , and ts- 47 were downregulated in lung cancer [25]. A functional enrichment study showed that ts-46 was associated with excessive activation of integrin-linked kinase (ILK) signaling, integrin signaling, platelet-derived growth factor (PDGF) signaling, sphingosine-1-phosphate (S1P) signaling, and mTOR signaling, while ts-101 was related to the overactivation of S1P signaling and glutamate receptor signaling. Both ts- 46 and ts-101 were correlated with the inhibition of phosphatase and tensin homolog (PTEN) and ceramide signaling [25]. ILK is a serine/threonine protein phosphatase and related to tumor growth and metastasis [112]. RNA silencing of ILK enhances cisplatin sensitivity in lung adenocarcinoma by regulating the downstream genes p-GSK3 $\beta, \mathrm{p}$-AKT, AP-1, $\beta$-catenin, cyclin D1, and MMP-9 [113]. ILK participates in the resistance of lung cancer to gemcitabine through EMT and MRP1 [112]. Integrins are transmembrane proteins that can control aggressive behaviors of tumors [114]. Integrin stimulates ILK by binding to extracellular matrix components and further activates the protein kinase B/Akt. Akt activity determines resistance to cisplatin [113]. Integrin mediates EGFR-TKIs resistance through EMT, the KRAS-RalB-NF- $\mathrm{KB}$ pathway, and the Src/Akt pathway [115-118]. The integrin $\alpha(v) \beta_{3} /$ Src/Akt pathway confers NSCLC cells resistance to anti-IGF1R monoclonal antibody cixutumumab [119]. PDGF/PDGFR may be one of the mechanisms of excision repair cross-complementing 1 (ERCC1)-mediated cisplatin resistance [120]. PI3K/AKT/mTOR signaling promotes chemoresistance in lung cancer [121-123]. PTEN is a major negative regulator of the PI3K pathway [25]. PTEN inactivation is related to EGFR-TKIs resistance [124, 125]. Silencing of PTEN induces resistance to cisplatin and paclitaxel through the PI3K/Akt pathway in NSCLC [126-128]. ts-46 and ts-47 can counteract carcinogenic effects of KRAS mutations and simultaneously positively affect the p53 pathway [25]. 


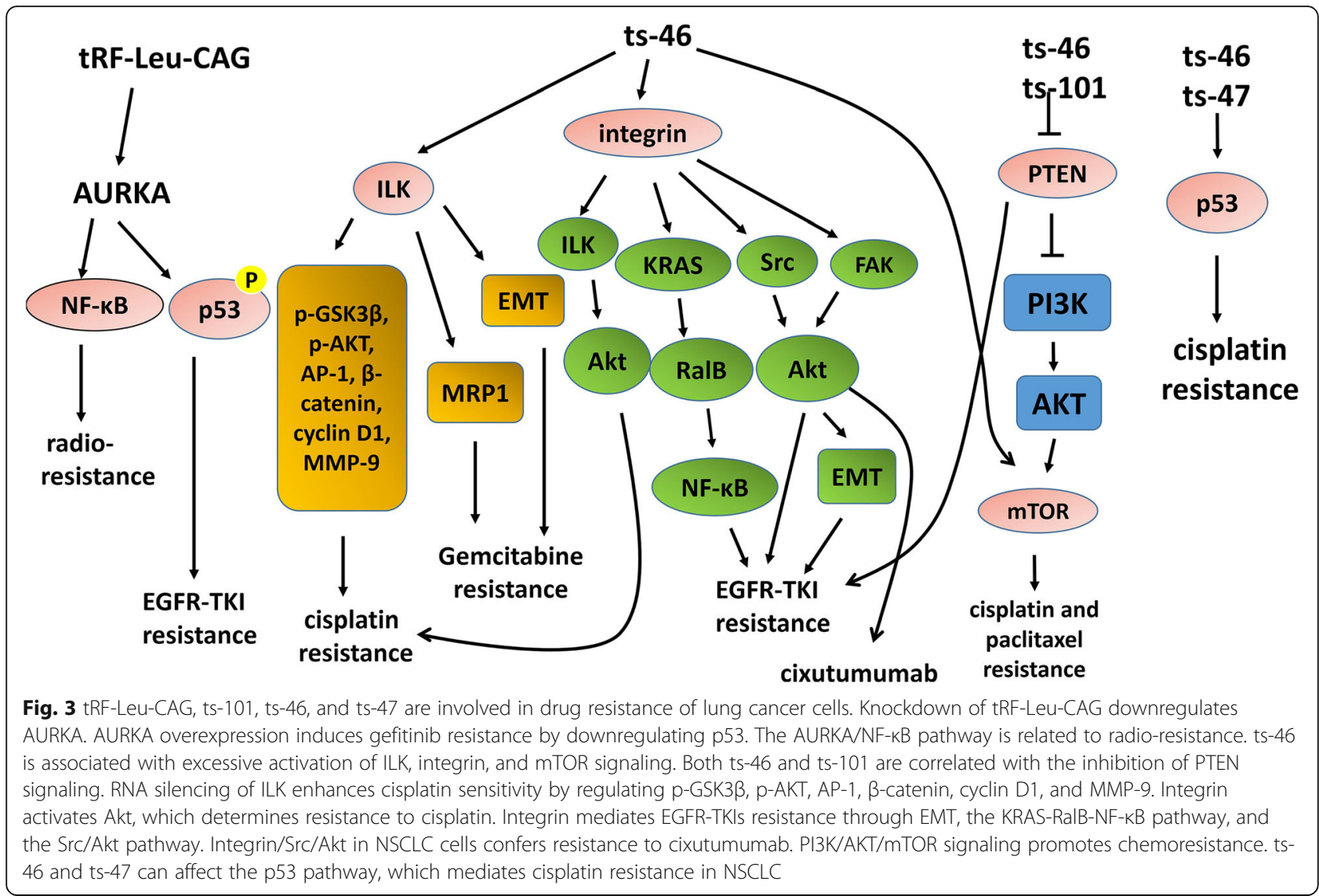

The P53 pathway mediates cisplatin resistance in NSCL $C[129,130]$. These data indicate that ts-101, ts-46, and ts -47 may be involved in drug resistance of lung cancer cells. (Fig. 3).

\section{Mechanisms of pancreatic cancer resistance related to tRFs and tiRNAs}

Pancreatic cancer (PC) has a high mortality rate, and the 5-year survival rate of patients with PC is only 8\% [131]. Jin et al. reported that tRF-1391 and AS-tDR-000064 were associated with PC [28]. The KEGG pathway analysis showed that target genes of tRF-1391 were mainly concentrated in the PI3K/Akt pathway and 18 target genes of AS-tDR-000064 were related to resistance to EGFR-TKIs [28]. Metformin mediates PI3K/Akt/mTOR signaling, thereby enhancing the sensitivity of gemcitabine treatment in PC [132]. Furthermore, the PI3K/AKT signaling pathway is related to doxorubicin resistance in PC [56]. The roles of tRFs in drug resistance of PC need further research.

\section{Mechanisms of colorectal cancer resistance related to tRFs and tiRNAs}

Colorectal cancer (CRC) ranks third in morbidity and mortality among all tumors [70]. Chemoresistance leads to a low response rate to chemotherapy in advanced CRC [133]. Huang et al. reported that tRF/miR-1280 expression was reduced in CRC. tRF/miR-1280 was derived from tRNALeu and pre-miRNA. In addition, the miR200b level decreased and Jagged-2 (JAG2), Gata1, Gata3, and zinc finger E-box binding homeobox 1 (Zeb1) levels increased in CRC [29]. JAG2 is a Notch ligand and is involved in tumor initiation and maintenance [134]. Gata factors are zinc finger DNA-binding proteins that control tissue development through the activation or repression of transcription [135]. tRF/miR-1280 binds to $3^{\prime}$-UTR of JAG2, thus inhibiting Notch/Gata and miR$200 \mathrm{~b}$ signaling. The inactivation of Notch signal mediated by tRF/miR-1280 inhibits CSC phenotype through transcriptional repressing of Gata1/3 and miR-200b and further inhibits cell proliferation and metastasis in CRC [29]. Ectopic expression of JAG2 mediates drug resistance in CRC. JAG2 regulates the sensitivity of CRC cells to chemotherapeutic drugs through p21 [136]. Notch signaling regulates cell proliferation, differentiation, and apoptosis [137] and is related to chemoresistance of colorectal CSCs [138]. Notch-1 mediates regorafenib resistance [137]. Reversing Notch signaling sensitizes CRC cells to 5-fluorouracil (5-FU) and irinotecan [139]. In addition, $\mathrm{tRF} / \mathrm{miR}-1280$ downregulated the expression of 
Gata1 and Gata3 through the Notch pathway. Gata binds to miR-200b to inhibit transcription initiation. Inhibition of Gata1 increases miR-200b expression and reduces EMT [29]. EMT and miR-200b are involved in chemoresistance of CRC [140, 141]. Furthermore, Zeb1 and miR-200b regulate each other negatively. The genes ubiquitin-specific peptidase 17, chromodomain helicase DNA-binding protein 1-like, and double homeobox 4 are associated with DNA damage response. The inhibitory effect of Zeb1 on these three genes induces drug resistance [142]. In summary, tRF/miR-1280 may be involved in chemotherapy resistance of CRC. Drugs that targeting tRF/miR-1280 may reverse drug resistance in future treatment and prolong survival.

Wang et al. reported that tiRNA-Tyr-GTA and tRFGln-CTG were upregulated, while tRF-Leu-TAG was downregulated in CRC [30]. The tiRNA-Tyr-GTA, tRFGln-CTG, and tRF-Leu-TAG are tiRNA-5, tRF-5c, and tRF-5a with lengths of 30,29 , and $16 \mathrm{nt}$, respectively. The GO and KEGG pathway analysis indicated that the functions of tiRNA-Tyr-GTA targets are mainly negative regulation of epithelial cell apoptotic and peroxisome proliferator activated-receptor (PPAR) pathway [30]. PPAR is a ligand-activated transcription factor and is involved in regulating cancer progression [143]. The PPAR pathway is related to radiation resistance in CRC [144]. Inhibition of PPAR $\alpha$ expression confers resistance to hydroxycamptothecin [145]. PPAR $\delta$ confers resistance to PPAR $\gamma$-induced apoptosis in CRC through mediation of survivin and caspase-3 [146]. In addition, tRF-Gln-CTG enhances the negative regulation of c-Jun $\mathrm{N}$-terminal kinase (JNK) cascade and choline metabolism, while tRF-Leu-TAG enhances MET function [30]. Silencing of the JNK1 gene can dephosphorylate c-Jun and reduce transport of the $\mathrm{G} 2$ subfamily of $\mathrm{ABC}$ transporters (ABCG2). The JNK1/c-jun pathway is related to ABCG2mediated multidrug resistance in CRC [147]. JNK activation can confer resistance to 5-FU in CRC patients with p53 mutation by inducing Bcl-2 phosphorylation [148]. Taken together, tiRNA-Tyr-GTA, tRF-Gln-CTG, and tRF-LeuTAG may be involved in chemoresistance of CRC.

\section{Mechanisms of ovarian cancer resistance related to tRFs and tiRNAs}

Ovarian cancer (OC) is the fourth most common gynecological malignant tumor with high drug resistance [149]. High grade serous ovarian cancer (HGSOC) accounts for $75 \%$ of OC cases. Zhang et al. identified 27 differentially expressed tRFs, such as tRF-03357 and tRF-03358, from serum samples of patients with HGSOC and healthy controls. These 27 tRFs are involved in the MAPK, FoxO, and Wnt pathways [40]. Most patients with advanced OC develop treatment resistance [150]. MAPK is associated with acquired chemoresistance of OC [151]. The C-KIT/MAPK/
MEK pathway establishes a link between platinum resistance and CSC phenotype in OC [152]. The RasMAPK/Erk-ETS1-ELK1/CFTR1 axis confers resistance to cisplatin [153]. The ERK/MAPK pathway promotes EMT phenotype, which is accompanied by increased cisplatin resistance [154]. The p38 MAPK activation upregulates p-glycoprotein expression, which enhances drug efflux, thereby inducing $\mathrm{OC}$ cell resistance to paclitaxel [155]. In addition, the activation of Wnt and its downstream molecules Wnt5a, $\beta$-catenin, c-Myc, and cyclin D1 upregulates the glycolysis level, thereby inducing cisplatin resistance in OC [156]. Fukumoto et al. showed that N6-methyladenosine of Frizzled family receptor 10 mRNA promoted resistance to poly (ADP)-ribose polymerase inhibitors (PARPi) by upregulating the Wnt/ $\beta$-catenin pathway in BRCA-mutated epithelial ovarian cancer (EOC) [157]. FoxO proteins have been reported to affect the effectiveness of anticancer drug treatment. Reduced FoxO1 expression is related to resistance to cisplatin [158]. To summarize, these differentially expressed tRFs affect the sensitivity of OC to chemotherapy, especially to cisplatin.

In addition, Zhou et al. reported that tRF5-Glu was expressed in OC. The tRF5-Glu binds to breast cancer antiestrogen resistance 3 (BCAR3) and downregulates its expression. BCAR3 and tRF5-Glu contribute to heterogeneity of OC [39]. Overexpression of BCAR induces antiestrogen resistance in breast cancer cells; however, it remains unclear whether BCAR has a similar effect in OC resistance $[159,160]$.

\section{Mechanisms of chronic lymphocytic leukemia resistance related to tRFs and tiRNAs}

Balatti et al. found that ts-101, ts-53, ts-46, and ts-47 were downregulated in chronic lymphocytic leukemia (CLL) [25]. As mentioned before, ts-46 is associated with integrin and ceramide signaling. ts-101 is correlated with ceramide signaling inhibition [25]. The combination of fibronectin and $\alpha 4 \beta 1$ integrin induces fludarabine resistance in B-cell CLL by upregulating Bcl-xL [161]. Ceramide metabolism is related to fludarabine resistance in CLL [162]. In addition, the downregulation of ts-53 increases the TCL1 expression level, leading to the progression of CLL [42]. However, the role of TCL1 in chemoresistance of CLL remains unclear.

\section{Techniques for studying tRFs and tiRNAs}

In the process of studying tRF and tiRNA, it is quite important to differentiate between tRFs and randomly degraded fragments. By using specific amplification primers, tRFs and tiRNAs can be specifically detected by quantitative reverse transcription-polymerase chain reaction (qRT-PCR). The expression of tRFs and tiRNAs can also be detected by northern blot [1]. Splinted ligation assay can measure the 
levels of tRFs and tiRNAs. The assay depends on ligation between the 3 '-end of tRF and the 5 '-end of a ligation oligo, mediated through accurate annealing to a bridge oligo [31]. Microarray chips have been designed to study the expression of tRFs (shorter than $16 \mathrm{bp}$ ) in normal and tumor tissues [43]. Researchers have also established some databases to manage tRFs, such as trfdb (http://genome.bioch. virginia.edu/trfdb) [5], tRF2Cancer (http://rna.sysu.edu.cn/ tRFfinder/) [58], YM500v3 database (http://ngs.ym.edu.tw/ ym500/) [163], tRFexplorer (https://trfexplorer.cloud/) [164], and MINTbase v2.0 (http://cm.jefferson.edu/MINTbase/) [165]. Mitochondrial and Nuclear TRF mapping (MINTmap; https:/github.com/TJU-CMC-Org/MINTmap/) is a software package for rapid and detailed identification of tRFs in short RNA-seq datasets. MINTmap can explicitly calculate and report raw and standardized abundances of discovered tRFs [1]. New technologies have led to breakthroughs in the exploration of tRFs and tiRNAs.

\section{Conclusion}

It is very common for tumors to acquire resistance to anticancer drugs. There is an urgent need to elucidate molecular mechanisms of cancer chemoresistance. This review outlines the classification of tRFs and tiRNAs, their roles in cancers, the mechanisms by which they play a role in cancer drug resistance, and the techniques for studying them. Their high equivalent and stability in body fluids, and differential expression between cancer patients and healthy controls open up broad prospects to develop screening, diagnostic, and prognostic biomarkers and targeted anticancer drugs that enhance the sensitivity of chemotherapeutic drugs. As the field is still in its infancy, it is a major challenge to fully understand the mechanism network of tRFs and tiRNAs in drug resistance. Overall, tRFs and tiRNAs give hope for cancer treatment, but further studies are required before clinical application. More work needs to be done to study broader and deeper mechanisms of tRFs and tiRNAs in drug resistance and the crosstalk between various signaling pathways.

\footnotetext{
Abbreviations

tRFs: tRNA-derived Fragments; tiRNAs: tRNA halves; tRNA: transfer RNA; nt: Nucleotide; tiRNA-5: 5'-tRNA half; tiRNA-3: 3'-tRNA half; elF4G: Eukaryotic translation initiation factor $4 \mathrm{G}$; $\mathrm{ABC}$ : Adenosine triphosphate-binding cassette; NSCLC: Non-small cell lung cancer; CRPA: Castration-resistant prostate cancer; SGs: Stress granules; TNBC: Triple-negative breast cancer; CSCs: Cancer stem cells; GO: Gene Ontology; KEGG: Kyoto Encyclopedia of Genes and Genome; IL: Interleukin; JAK: Janus kinase; STAT3: Signal transducer and activator of transcription 3; PI3K: Phosphoinositide-3-kinase; Akt: Protein Kinase B; MAPK: Mitogen-activated protein kinase; Bax: $\mathrm{BCl}$-2-associated x protein mTOR: Mammalian target of rapamycin; P-gp: P-glycoprotein; MRP1: Multidrug Resistance Protein 1; Hh: Hedgehog; ER: Estrogen receptor; IGF2: Insulin-like growth factor 2; IGF1R: Insulin-like growth factor receptor 1; IR-A: Insulin receptor A; HER2: Human epidermal growth factor receptor-2; EMT: Epithelial-to-mesenchymal transition; FZD3: Frizzled homolog 3; APC: Adenomatous polyposis coli; TIC: Tumor initiating cell; YBX1: Y BoxBinding Protein 1; ESCC: Esophageal squamous cell carcinoma; EGFR-
}

TKls: Epidermal growth factor receptor tyrosine kinase inhibitors; ILK: Integrinlinked kinase; PDGF: Platelet-derived growth factor; S1P: Sphingosine-1phosphate; PTEN: Phosphatase and tensin homolo; PC: Pancreatic cancer; CRC: Colorectal cancer; Zeb1: Zinc finger E-box binding homeobox 1; EMT: Epithelial-mesenchymal transition; PPAR: Peroxisome proliferator activatedreceptors; JNK: c-Jun N-terminal kinase; ABCG2: G2 subfamily of ABC transporters; OC: Ovarian cancer; HGSOC: High-grade serous ovarian cancer; BCAR3: Breast Cancer Anti-Estrogen Resistance 3; CLL: Chronic lymphocytic leukemia

\section{Acknowledgements \\ Not applicable.}

\section{Authors' contributions}

All authors contributed in the planning and writing of this review article. WG and $\mathrm{JH}$ are co-corresponding authors. $\mathrm{YZ}$ and $\mathrm{HQ}$ are co-first authors. The authors read and approved the final manuscript.

\section{Funding}

This work was supported by grants from the National Natural Science Foundation of China (81572262), the Jiangsu Province's Key Provincial Talents Program (ZDRCA2016028), 333 high class Talented Man Project (BRA2016516) and the Natural Science Foundation of the Jiangsu Higher Education Institution of China (18KJB320006)

Availability of data and materials

Not applicable.

Ethics approval and consent to participate

Not applicable.

Consent for publication

Not applicable.

\section{Competing interests}

The authors declare that they have no competing interests.

Received: 4 August 2020 Accepted: 2 October 2020

Published online: 15 October 2020

\section{References}

1. Zhu L, Ge J, Li T, Shen $Y$, Guo J. tRNA-derived fragments and tRNA halves: the new players in cancers. Cancer Lett. 2019;452:31-7.

2. Sobala A, Hutvagner G. Transfer RNA-derived fragments: origins, processing, and functions. Wiley interdisciplinary reviews RNA. 2011;2(6):853-62.

3. Soares AR, Santos M. Discovery and function of transfer RNA-derived fragments and their role in disease. Wiley interdisciplinary reviews RNA. 2017:8(5).

4. Keam SP, Hutvagner G. tRNA-Derived Fragments (tRFs): Emerging New Roles for an Ancient RNA in the Regulation of Gene Expression. Life (Basel, Switzerland). 2015;5(4):1638-51.

5. Sun C, Fu Z, Wang S, Li J, Li Y, Zhang Y, et al. Roles of tRNA-derived fragments in human cancers. Cancer Lett. 2018:414:16-25.

6. Zhang S, Li H, Zheng L, Li H, Feng C, Zhang W. Identification of functional tRNA-derived fragments in senescence-accelerated mouse prone 8 brain. Aging. 2019;11(22):10485-98.

7. Liao JY, Ma LM, Guo YH, Zhang YC, Zhou H, Shao P, et al. Deep sequencing of human nuclear and cytoplasmic small RNAs reveals an unexpectedly complex subcellular distribution of miRNAs and tRNA 3' trailers. PLoS One. 2010;5(5):e10563.

8. Kumar P, Kuscu C, Dutta A. Biogenesis and function of transfer RNA-related fragments (tRFs). Trends Biochem Sci. 2016;41(8):679-89.

9. Telonis AG, Loher $P$, Honda S, Jing $Y$, Palazzo J, Kirino $Y$, et al. Dissecting tRNA-derived fragment complexities using personalized transcriptomes reveals novel fragment classes and unexpected dependencies. Oncotarget. 2015:6(28):24797-822

10. Yamasaki S, Ivanov P, Hu GF, Anderson P. Angiogenin cleaves tRNA and promotes stress-induced translational repression. J Cell Biol. 2009;185(1):3542

11. Thompson DM, Parker R. Stressing out over tRNA cleavage. Cell. 2009:138(2): 215-9. 
12. Sun C, Yang F, Zhang Y, Chu J, Wang J, Wang Y, et al. tRNA-derived fragments as novel predictive biomarkers for Trastuzumab-resistant breast Cancer. Cell Physiol Biochem. 2018;49(2):419-31.

13. Cui $Y$, Huang $Y, W u X$, Zheng $M, X i a ~ Y, F u ~ Z$, et al. Hypoxia-induced tRNAderived fragments, novel regulatory factor for doxorubicin resistance in triple-negative breast cancer. J Cell Physiol. 2019;234(6):8740-51.

14. Qin JJ, Yan L, Zhang J, Zhang WD. STAT3 as a potential therapeutic target in triple negative breast cancer: a systematic review. J Exp Clin Cancer Res. 2019;38(1):195

15. Falconi M, Giangrossi M, Zabaleta ME, Wang J, Gambini V, Tilio M, et al. A novel 3'-tRNA (Glu)-derived fragment acts as a tumor suppressor in breast cancer by targeting nucleolin. FASEB J. 2019;33(12):13228-40.

16. Huang $Y, G$ G H, Zheng $M$, Cui $Y, F u Z$, Wu $X$, et al. Serum tRNA-derived fragments (tRFs) as potential candidates for diagnosis of nontriple negative breast cancer. J Cell Physiol. 2020;235(3):2809-24.

17. Farina $\mathrm{NH}$, Scalia S, Adams CE, Hong D, Fritz AJ, Messier TL, et al. Identification of tRNA-derived small RNA (tsRNA) responsive to the tumor suppressor, RUNX1, in breast cancer. J Cell Physiol. 2020;235(6):5318-27.

18. Mo D, Jiang $P$, Yang $Y$, Mao $X$, Tan X, Tang $X$, et al. A tRNA fragment, 5'tiRNA ( $\mathrm{Val})$, suppresses the $W n t / \beta$-catenin signaling pathway by targeting FZD3 in breast cancer. Cancer Lett. 2019;457:60-73.

19. Wang X, Yang Y, Tan X, Mao X, Wei D, Yao Y, et al. Identification of tRNAderived fragments expression profile in breast Cancer tissues. Curr Genom 2019;20(3):199-213.

20. Honda S, Loher P, Shigematsu M, Palazzo JP, Suzuki R, Imoto I, et al. Sex hormone-dependent tRNA halves enhance cell proliferation in breast and prostate cancers. Proc Natl Acad Sci U S A. 2015;112(29):E3816-25.

21. Feng $W$, Li Y, Chu J, Li J, Zhang $Y$, Ding $X$, et al. Identification of tRNAderived small noncoding RNAs as potential biomarkers for prediction of recurrence in triple-negative breast cancer. Cancer Med. 2018;7(10):5130-44.

22. Santarpia L, Bottai G, Kelly CM, Győrffy B, Székely B, Pusztai L. Deciphering and targeting oncogenic mutations and pathways in breast Cancer. Oncologist. 2016;21(9):1063-78.

23. Goodarzi H, Liu X, Nguyen HC, Zhang S, Fish L, Tavazoie SF. Endogenous tRNA-derived fragments suppress breast Cancer progression via YBX1 displacement. Cell. 2015;161(4):790-802.

24. Babiarz JE, Ruby JG, Wang Y, Bartel DP, Blelloch R. Mouse ES cells express endogenous shRNAs, siRNAs, and other microprocessor-independent, dicerdependent small RNAs. Genes Dev. 2008;22(20):2773-85.

25. Balatti V, Nigita G, Veneziano D, Drusco A, Stein GS, Messier TL, et al. tsRNA signatures in cancer. Proc Natl Acad Sci U S A. 2017;114(30):8071-6.

26. Zeng T, Hua Y, Sun C, Zhang Y, Yang F, Yang M, et al. Relationship between tRNA-derived fragments and human cancers. Int J Cancer. 2020.

27. Shao Y, Sun Q, Liu X, Wang P, Wu R, Ma Z. tRF-Leu-CAG promotes cell proliferation and cell cycle in non-small cell lung cancer. Chem Biol Drug Des. 2017;90(5):730-8.

28. Jin L, Zhu C, Qin X. Expression profile of tRNA-derived fragments in pancreatic cancer. Oncol Lett. 2019;18(3):3104-14.

29. Huang $B$, Yang $H$, Cheng $X$, Wang D, Fu S, Shen W, et al. tRF/miR-1280 suppresses stem cell-like cells and metastasis in colorectal Cancer. Cancer Res. 2017;77(12):3194-206.

30. Wang X, Zhang Y, Ghareeb WM, Lin S, Lu X, Huang Y, et al. A comprehensive repertoire of transfer RNA-derived fragments and their regulatory networks in colorectal Cancer. J Computational Biol. 2020.

31. Lee YS, Shibata Y, Malhotra A, Dutta A. A novel class of small RNAs: tRNAderived RNA fragments (tRFs). Genes Dev. 2009;23(22):2639-49.

32. Olvedy M, Scaravilli M, Hoogstrate $Y$, Visakorpi T, Jenster G, MartensUzunova ES. A comprehensive repertoire of tRNA-derived fragments in prostate cancer. Oncotarget. 2016;7(17):24766-77.

33. Fu H, Feng J, Liu Q, Sun F, Tie Y, Zhu J, et al. Stress induces tRNA cleavage by angiogenin in mammalian cells. FEBS Lett. 2009;583(2):437-42.

34. Sobala A, Hutvagner G. Small RNAs derived from the $5^{\prime}$ end of tRNA can inhibit protein translation in human cells. RNA Biol. 2013;10(4):553-63.

35. Nientiedt M, Deng M, Schmidt D, Perner S, Müller SC, Ellinger J. Identification of aberrant tRNA-halves expression patterns in clear cell renal cell carcinoma. Sci Rep. 2016;6:37158.

36. Zhao C, Tolkach Y, Schmidt D, Kristiansen G, Müller SC, Ellinger J. 5'-tRNA halves are Dysregulated in clear cell renal cell carcinoma. J Urol. 2018;199(2): 378-83

37. Maute RL, Schneider C, Sumazin P, Holmes A, Califano A, Basso K, et al. tRNA-derived microRNA modulates proliferation and the DNA damage response and is down-regulated in B cell lymphoma. Proc Natl Acad Sci U S A. 2013;110(4):1404-9.

38. Li Z, Ender C, Meister G, Moore PS, Chang Y, John B. Extensive terminal and asymmetric processing of small RNAs from rRNAs, snoRNAs, snRNAs, and tRNAs. Nucleic Acids Res. 2012;40(14):6787-99.

39. Zhou K, Diebel KW, Holy J, Skildum A, Odean E, Hicks DA, et al. A tRNA fragment, tRF5-Glu, regulates BCAR3 expression and proliferation in ovarian cancer cells. Oncotarget. 2017:8(56):95377-91.

40. Zhang M, Li F, Wang J, He W, Li Y, Li H, et al. tRNA-derived fragment tRF03357 promotes cell proliferation, migration and invasion in high-grade serous ovarian cancer. OncoTargets Ther. 2019;12:6371-83.

41. Ivanov P, O'Day E, Emara MM, Wagner G, Lieberman J, Anderson P. Gquadruplex structures contribute to the neuroprotective effects of angiogenin-induced tRNA fragments. Proc Natl Acad Sci U S A. 2014; 111(51):18201-6.

42. Balatti V, Rizzotto L, Miller C, Palamarchuk A, Fadda P, Pandolfo R, et al. TCL1 targeting miR-3676 is codeleted with tumor protein p53 in chronic lymphocytic leukemia. Proc Natl Acad Sci U S A. 2015;112(7):2169-74.

43. Pekarsky Y, Balatti V, Palamarchuk A, Rizzotto L, Veneziano D, Nigita G, et al. Dysregulation of a family of short noncoding RNAs, tsRNAs, in human cancer. Proc Natl Acad Sci U S A. 2016;113(18):5071-6.

44. Katsaraki K, Artemaki PI, Papageorgiou SG, Pappa V, Scorilas A, Kontos CK. Identification of a novel, internal tRNA-derived RNA fragment as a new prognostic and screening biomarker in chronic lymphocytic leukemia, using an innovative quantitative real-time PCR assay. Leuk Res. 2019;87:106234.

45. Karousi P, Katsaraki K, Papageorgiou SG, Pappa V, Scorilas A, Kontos CK. Identification of a novel tRNA-derived RNA fragment exhibiting high prognostic potential in chronic lymphocytic leukemia. Hematol Oncol. 2019;37(4):498-504.

46. Veneziano D, Tomasello L, Balatti V, Palamarchuk A, Rassenti LZ, Kipps TJ, et al. Dysregulation of different classes of tRNA fragments in chronic lymphocytic leukemia. Proc Natl Acad Sci U S A. 2019;116(48):24252-8.

47. Victoria Martinez B, Dhahbi JM, Nunez Lopez YO, Lamperska K, Golusinski $P$, Luczewski $L$, et al. Circulating small non-coding RNA signature in head and neck squamous cell carcinoma. Oncotarget. 2015;6(22):19246-63.

48. Londin E, Magee R, Shields CL, Lally SE, Sato T, Rigoutsos I. IsomiRs and tRNA-derived fragments are associated with metastasis and patient survival in uveal melanoma. Pigment Cell Melanoma Res. 2020;33(1):52-62.

49. Zhang F, Shi J, Wu Z, Gao P, Zhang W, Qu B, et al. A 3'-tRNA-derived fragment enhances cell proliferation, migration and invasion in gastric cancer by targeting FBXO47. Arch Biochem Biophys. 2020;690:108467.

50. Wang $Y$, Niu XL, Qu Y, Wu J, Zhu YQ, Sun WJ, et al. Autocrine production of interleukin-6 confers cisplatin and paclitaxel resistance in ovarian cancer cells. Cancer Lett. 2010;295(1):110-23.

51. Hou Y, Li X, Li Q, Xu J, Yang H, Xue M, et al. STAT1 facilitates oestrogen receptor a transcription and stimulates breast cancer cell proliferation. J Cell Mol Med. 2018;22(12):6077-86.

52. Feng WW, Kurokawa M. Lipid metabolic reprogramming as an emerging mechanism of resistance to kinase inhibitors in breast cancer. Cancer Drug Resistance (Alhambra, Calif). 2020;3(1). https://doi.org/10.20517/cdr.2019.100.

53. Wang H, Sun R, Chi Z, Li S, Hao L. Silencing of Y-box binding protein-1 by RNA interference inhibits proliferation, invasion, and metastasis, and enhances sensitivity to cisplatin through NF-KB signaling pathway in human neuroblastoma SH-SY5Y cells. Mol Cell Biochem. 2017;433(1-2):1-12.

54. Chen J, Lu H, Zhou W, Yin H, Zhu L, Liu C, et al. AURKA upregulation plays a role in fibroblast-reduced gefitinib sensitivity in the NSCLC cell line HCC827. Oncol Rep. 2015;33(4):1860-6.

55. Xu J, Yue CF, Zhou WH, Qian YM, Zhang Y, Wang SW, et al. Aurora-a contributes to cisplatin resistance and lymphatic metastasis in non-smal cell lung cancer and predicts poor prognosis. J Transl Med. 2014;12:200

56. Han GY, Cui JH, Liang S, Li HL. Increased miR-142 and decreased DJ-1 enhance the sensitivity of pancreatic cancer cell to adriamycin. Eur Rev Med Pharmacol Sci. 2018:22(22):7696-703

57. Kim HK, Fuchs G, Wang S, Wei W, Zhang Y, Park H, et al. A transferRNA-derived small RNA regulates ribosome biogenesis. Nature. 2017; 552(7683):57-62.

58. Zheng LL, Xu WL, Liu S, Sun WJ, Li JH, Wu J, et al. tRF2Cancer: a web server to detect tRNA-derived small RNA fragments (tRFs) and their expression in multiple cancers. Nucleic Acids Res. 2016:44(W1):W185-93.

59. Niu J, Xue A, Chi Y, Xue J, Wang W, Zhao Z, et al. Induction of miRNA-181a by genotoxic treatments promotes chemotherapeutic resistance and metastasis in breast cancer. Oncogene. 2016;35(10):1302-13. 
60. Pan X, Yang X, Zang J, Zhang S, Huang N, Guan X, et al. Downregulation of elF4G by microRNA-503 enhances drug sensitivity of MCF-7/ADR cells through suppressing the expression of $A B C$ transport proteins. Oncol Lett. 2017;13(6):4785-93.

61. Sharom FJ. ABC multidrug transporters: structure, function and role in chemoresistance. Pharmacogenomics. 2008;9(1):105-27.

62. Hao GJ, Hao HJ, Ding YH, Wen H, Li XF, Wang QR, et al. Suppression of EIF4G2 by miR-379 potentiates the cisplatin chemosensitivity in nonsmall cell lung cancer cells. FEBS Lett. 2017;591(4):636-45.

63. Zindy P, Bergé Y, Allal B, Filleron T, Pierredon S, Cammas A, et al. Formation of the elF4F translation-initiation complex determines sensitivity to anticancer drugs targeting the EGFR and HER2 receptors. Cancer Res. 2011; 71(12):4068-73.

64. Fagan DH, Fettig LM, Avdulov S, Beckwith $H$, Peterson MS, Ho YY, et al. Acquired Tamoxifen resistance in MCF-7 breast Cancer cells requires Hyperactivation of elF4F-mediated translation. Hormones Cancer. 2017; 8(4):219-29.

65. Jaiswal PK, Koul S, Shanmugam PST, Koul HK. Eukaryotic translation initiation factor 4 gamma 1 (elF4G1) is upregulated during prostate cancer progression and modulates cell growth and metastasis. Sci Rep. 2018:8(1):7459.

66. Bittencourt LFF, Negreiros-Lima GL, Sousa LP, Silva AG, Souza IBS, Ribeiro R, et al. G3BP1 knockdown sensitizes U87 glioblastoma cell line to Bortezomib by inhibiting stress granules assembly and potentializing apoptosis. J Neuro-Oncol. 2019;144(3):463-73.

67. Christen KE, Davis RA, Kennedy D. Psammaplysin F increases the efficacy of bortezomib and sorafenib through regulation of stress granule formation. Int J Biochem Cell Biol. 2019;112:24-38.

68. Timalsina S, Arimoto-Matsuzaki K, Kitamura M, Xu X, Wenzhe Q, IshigamiYuasa $\mathrm{M}$, et al. Chemical compounds that suppress hypoxia-induced stress granule formation enhance cancer drug sensitivity of human cervical cancer HeLa cells. J Biochem. 2018;164(5):381-91.

69. Yagüe $E$, Raguz $\mathrm{S}$. Escape from stress granule sequestration: another way to drug resistance? Biochem Soc Trans. 2010;38(6):1537-42.

70. Siegel RL, Miller KD, Jemal A. Cancer statistics, 2020. CA Cancer J Clin. 2020; 70(1):7-30.

71. VanKlompenberg MK, Leyden E, Arnason AH, Zhang JT, Stefanski CD, Prosperi JR. APC loss in breast cancer leads to doxorubicin resistance via STAT3 activation. Oncotarget. 2017;8(61):102868-79.

72. Nedeljković M, Damjanović A. Mechanisms of Chemotherapy Resistance in Triple-Negative Breast Cancer-How We Can Rise to the Challenge. Cells. 2019;8(9):957.

73. Kuo WY, Hwu L, Wu CY, Lee JS, Chang CW, Liu RS. STAT3/NF-kB-regulated Lentiviral TK/GCV suicide gene therapy for Cisplatin-resistant triple-negative breast Cancer. Theranostics. 2017;7(3):647-63.

74. Egusquiaguirre SP, Yeh JE, Walker SR, Liu S, Frank DA. The STAT3 Target Gene TNFRSF1A Modulates the NF-KB Pathway in Breast Cancer Cells. Neoplasia (New York, NY). 2018;20(5):489-98.

75. Liu J, Yang Y, Wang H, Wang B, Zhao K, Jiang W, et al. Syntenin1/MDA-9 (SDCBP) induces immune evasion in triple-negative breast cancer by upregulating PD-L1. Breast Cancer Res Treat. 2018;171(2):345-57..

76. Hamilton N, Austin D, Márquez-Garbán D, Sanchez R, Chau B, Foos K, et al. Receptors for Insulin-Like Growth Factor-2 and Androgens as Therapeutic Targets in Triple-Negative Breast Cancer. Int J Mol Sci. 2017;18(11):2305.

77. Yuan J, Yin Z, Tao K, Wang G, Gao J. Function of insulin-like growth factor 1 receptor in cancer resistance to chemotherapy. Oncol Lett. 2018;15(1):41-7.

78. Lesniak D, Sabri S, Xu Y, Graham K, Bhatnagar P, Suresh M, et al. Spontaneous epithelial-mesenchymal transition and resistance to HER-2 targeted therapies in HER-2-positive luminal breast cancer. PLoS One. 2013; 8(8):e71987.

79. Sabbaghi M, Gil-Gómez G, Guardia C, Servitja S, Arpí O, García-Alonso S, et al. Defective Cyclin B1 induction in Trastuzumab-emtansine (T-DM1) acquired resistance in HER2-positive breast Cancer. Clin Cancer Res. 2017; 23(22):7006-19.

80. Dong XL, Xu PF, Miao C, Fu ZY, Li QP, Tang PY, et al. Hypoxia decreased chemosensitivity of breast cancer cell line MCF-7 to paclitaxel through cyclin B1. Biomedicine \& pharmacotherapy = Biomedecine \& pharmacotherapie. 2012;66(1):70-5.

81. Jeong SH, Joo EJ, Ahn YM, Lee KY, Kim YS. Investigation of genetic association between human frizzled homolog 3 gene (FZD3) and schizophrenia: results in a Korean population and evidence from metaanalysis. Psychiatry Res. 2006;143(1):1-11.

82. Henry C, Quadir A, Hawkins NJ, Jary E, Llamosas E, Kumar D, et al. Expression of the novel Wnt receptor ROR2 is increased in breast cancer and may regulate both $\beta$-catenin dependent and independent Wnt signalling. J Cancer Res Clin Oncol. 2015;141(2):243-54.

83. Alshaer W, Alqudah DA, Wehaibi S, Abuarqoub D, Zihlif M, Hatmal MM, et al. Downregulation of STAT3, $\beta$-Catenin, and Notch-1 by Single and Combinations of siRNA Treatment Enhance Chemosensitivity of Wild Type and Doxorubicin Resistant MCF7 Breast Cancer Cells to Doxorubicin. Int J Mol Sci. 2019;20(15):3696

84. Venditti M, Iwasiow B, Orr FW, Shiu RP. C-myc gene expression alone is sufficient to confer resistance to antiestrogen in human breast cancer cells. Int J Cancer. 2002;99(1):35-42.

85. Yin S, Cheryan VT, Xu L, Rishi AK, Reddy KB. Myc mediates cancer stem-like cells and EMT changes in triple negative breast cancers cells. PLoS One. 2017;12(8):e0183578.

86. Van der Auwera I, Van Laere SJ, Van den Bosch SM, Van den Eynden GG, Trinh BX, van Dam PA, et al. Aberrant methylation of the adenomatous polyposis coli (APC) gene promoter is associated with the inflammatory breast cancer phenotype. Br J Cancer. 2008:99(10):1735-42.

87. Prasad CP, Mirza S, Sharma G, Prashad R, DattaGupta S, Rath G, et al. Epigenetic alterations of $\mathrm{CDH} 1$ and APC genes: relationship with activation of Wnt/beta-catenin pathway in invasive ductal carcinoma of breast. Life Sci. 2008:83(9-10):318-25.

88. VanKlompenberg MK, Bedalov CO, Soto KF, Prosperi JR. APC selectively mediates response to chemotherapeutic agents in breast cancer. BMC Cancer. 2015;15:457.

89. Stefanski CD, Keffler K, McClintock S, Milac L, Prosperi JR. APC loss affects DNA damage repair causing doxorubicin resistance in breast cancer cells. Neoplasia (New York, NY). 2019;21(12):1143-50.

90. Wei W, Lewis MT. Identifying and targeting tumor-initiating cells in the treatment of breast cancer. Endocr Relat Cancer. 2015;22(3):R135-55.

91. Uchiumi T, Fotovati A, Sasaguri T, Shibahara K, Shimada T, Fukuda T, et al. YB-1 is important for an early stage embryonic development: neural tube formation and cell proliferation. J Biol Chem. 2006:281(52):40440-9.

92. Schittek B, Psenner K, Sauer B, Meier F, Iftner T, Garbe C. The increased expression of $\mathrm{Y}$ box-binding protein 1 in melanoma stimulates proliferation and tumor invasion, antagonizes apoptosis and enhances chemoresistance. Int J Cancer. 2007;120(10):2110-8.

93. Oda Y, Kohashi K, Yamamoto H, Tamiya S, Kohno K, Kuwano M, et al. Different expression profiles of $\mathrm{Y}$-box-binding protein-1 and multidrug resistance-associated proteins between alveolar and embryonal rhabdomyosarcoma. Cancer Sci. 2008:99(4):726-32.

94. Hyogotani A, Ito K, Yoshida K, Izumi H, Kohno K, Amano J. Association of nuclear YB-1 localization with lung resistance-related protein and epidermal growth factor receptor expression in lung cancer. Clin Lung Cancer. 2012; 13(5):375-84.

95. Shiota M, Kashiwagi E, Yokomizo A, Takeuchi A, Dejima T, Song Y, et al. Interaction between docetaxel resistance and castration resistance in prostate cancer: implications of Twist1, YB-1, and androgen receptor. Prostate. 2013;73(12):1336-44.

96. Shibata T, Kan H, Murakami Y, Ureshino H, Watari K, Kawahara A, et al, Y-box binding protein-1 contributes to both HER2/ErbB2 expression and lapatinib sensitivity in human gastric cancer cells. Mol Cancer Ther. 2013;12(5):737-46.

97. Fujita T, Ito K, Izumi H, Kimura M, Sano M, Nakagomi H, et al. Increased nuclear localization of transcription factor Y-box binding protein 1 accompanied by up-regulation of P-glycoprotein in breast cancer pretreated with paclitaxel. Clin Cancer Res. 2005;1 1(24 Pt 1):8837-44.

98. Chao HM, Huang HX, Chang PH, Tseng KC, Miyajima A, Chern E. Y-box binding protein-1 promotes hepatocellular carcinoma-initiating cell progression and tumorigenesis via Wnt/ $\beta$-catenin pathway. Oncotarget. 2017:8(2):2604-16

99. Oda Y, Ohishi Y, Basaki Y, Kobayashi H, Hirakawa T, Wake N, et al. Prognostic implications of the nuclear localization of Y-box-binding protein-1 and CXCR4 expression in ovarian cancer: their correlation with activated Akt. LRP/MVP and P-glycoprotein Expression Cancer Sci. 2007;98(7):1020-6.

100. Yamashita T, Higashi M, Momose S, Morozumi M, Tamaru J. Nuclear expression of $Y$ box binding-1 is important for resistance to chemotherapy including gemcitabine in TP53-mutated bladder cancer. Int J Oncol. 2017; 51(2):579-86. 
101. Miao X, Wu Y, Wang Y, Zhu X, Yin H, He Y, et al. Y-box-binding protein-1 (YB-1) promotes cell proliferation, adhesion and drug resistance in diffuse large B-cell lymphoma. Exp Cell Res. 2016;346(2):157-66.

102. Shiota M, Takeuchi A, Song Y, Yokomizo A, Kashiwagi E, Uchiumi T, et al. Ybox binding protein-1 promotes castration-resistant prostate cancer growth via androgen receptor expression. Endocr Relat Cancer. 2011;18(4):505-17.

103. Liang C, Ma Y, Yong L, Yang C, Wang P, Liu X, et al. Y-box binding protein-1 promotes tumorigenesis and progression via the epidermal growth factor receptor/AKT pathway in spinal chordoma. Cancer Sci. 2019;110(1):166-79.

104. Xu J, Hu Z. Y-box-binding protein 1 promotes tumor progression and inhibits cisplatin chemosensitivity in esophageal squamous cell carcinoma. Biomedicine \& pharmacotherapy = Biomedecine \& pharmacotherapie. 2016; 79:17-22.

105. Chua PJ, Lim JP, Guo TT, Khanna P, Hu Q, Bay BH, et al. Y-box binding protein-1 and STAT3 independently regulate ATP-binding cassette transporters in the chemoresistance of gastric cancer cells. Int J Oncol. 2018; 53(6):2579-89.

106. Kuwano M, Shibata T, Watari K, Ono M. Oncogenic Y-box binding protein-1 as an effective therapeutic target in drug-resistant cancer. Cancer Sci. 2019; 110(5):1536-43.

107. Chen W, Zheng R, Baade PD, Zhang S, Zeng H, Bray F, et al. Cancer statistics in China, 2015. CA Cancer J Clin. 2016;66(2):115-32.

108. Gautschi O, Heighway J, Mack PC, Purnell PR, Lara PN Jr, Gandara DR. Aurora kinases as anticancer drug targets. Clin Cancer Res. 2008;14(6): 1639-48.

109. Nishimura Y, Endo T, Kano K, Naito K. Porcine Aurora a accelerates Cyclin B and Mos synthesis and promotes meiotic resumption of porcine oocytes. Anim Reprod Sci. 2009;113(1-4):114-24

110. Shah KN, Bhatt R, Rotow J, Rohrberg J, Olivas V, Wang VE, et al. Aurora kinase a drives the evolution of resistance to third-generation EGFR inhibitors in lung cancer. Nat Med. 2019;25(1):111-8.

111. Liu JB, Hu L, Yang Z, Sun YU, Hoffman RM, Yi Z. Aurora-a/NF-kB signaling is associated with Radio-resistance in Human Lung Adenocarcinoma. Anticancer Res. 2019;39(11):5991-8.

112. Jia Z. Role of integrin-linked kinase in drug resistance of lung cancer. OncoTargets and therapy. 2015;8:1561-5.

113. Zhao X, Xu Z, Wang Z, Wu Z, Gong Y, Zhou L, et al. RNA silencing of integrin-linked kinase increases the sensitivity of the A549 lung cancer cell line to cisplatin and promotes its apoptosis. Mol Med Rep. 2015;12(1):960-6.

114. Aksorn N, Chanvorachote P. Integrin as a molecular target for anti-cancer approaches in lung Cancer. Anticancer Res. 2019;39(2):541-8.

115. Seguin L, Kato S, Franovic A, Camargo MF, Lesperance J, Elliott KC, et al. An integrin $\beta_{3}$-KRAS-RalB complex drives tumour stemness and resistance to EGFR inhibition. Nat Cell Biol. 2014;16(5):457-68.

116. Kanda R, Kawahara A, Watari K, Murakami Y, Sonoda K, Maeda M, et al. Erlotinib resistance in lung cancer cells mediated by integrin $\beta 1 / \mathrm{Src} / \mathrm{Akt}-$ driven bypass signaling. Cancer Res. 2013;73(20):6243-53.

117. Ju L, Zhou C. Integrin beta 1 enhances the epithelial-mesenchymal transition in association with gefitinib resistance of non-small cell lung cancer. Cancer biomarkers. 2013;13(5):329-36.

118. Ju L, Zhou C, Li W, Yan L. Integrin beta1 over-expression associates with resistance to tyrosine kinase inhibitor gefitinib in non-small cell lung cancer. J Cell Biochem. 2010;111(6):1565-74.

119. Shin DH, Lee HJ, Min HY, Choi SP, Lee MS, Lee JW, et al. Combating resistance to anti-IGFR antibody by targeting the integrin $\beta 3$-Src pathway. J Natl Cancer Inst. 2013;105(20):1558-70.

120. He L, Wang X, Liu K, Wu X, Yang X, Song G, et al. Integrative PDGF/PDGFR and focal adhesion pathways are downregulated in ERCC1-defective nonsmall cell lung cancer undergoing sodium glycididazole-sensitized cisplatin treatment. Gene. 2019;691:70-6.

121. Wu YY, Wu HC, Wu JE, Huang KY, Yang SC, Chen SX, et al. The dual PI3K mTOR inhibitor BEZ235 restricts the growth of lung cancer tumors regardless of EGFR status, as a potent accompanist in combined therapeutic regimens. J Exp Clin Cancer Res. 2019:38(1):282.

122. Lei L, Wang WX, Zhu YC, Li JL, Fang Y, Wang H, et al. Potential mechanism of primary resistance to icotinib in patients with advanced non-small cell lung cancer harboring uncommon mutant epidermal growth factor receptor: a multi-center study. Cancer Sci. 2020;111(2):679-86.

123. Teng X, Fan XF, Li Q, Liu S, Wu DY, Wang SY, et al. XPC inhibition rescues cisplatin resistance via the Akt/mTOR signaling pathway in A549/DDP lung adenocarcinoma cells. Oncol Rep. 2019;41(3):1875-82.
124. Pérez-Ramírez C, Cañadas-Garre M, Molina M, Faus-Dáder MJ, CallejaHernández M. PTEN and PI3K/AKT in non-small-cell lung cancer. Pharmacogenomics. 2015;16(16):1843-62.

125. Zhong J, Li L, Wang Z, Bai H, Gai F, Duan J, et al. Potential resistance mechanisms revealed by targeted sequencing from lung adenocarcinoma patients with primary resistance to epidermal growth factor receptor (EGFR) tyrosine kinase inhibitors (TKIs). J Thoracic Oncol. 2017;12(12):1766-78.

126. Lu C, Wang H, Chen S, Yang R, Li H, Zhang G. Baicalein inhibits cell growth and increases cisplatin sensitivity of A549 and H460 cells via miR-424-3p and targeting PTEN/PI3K/Akt pathway. J Cell Mol Med. 2018;22(4):2478-87.

127. De Marco C, Laudanna C, Rinaldo N, Oliveira DM, Ravo M, Weisz A, et al. Specific gene expression signatures induced by the multiple oncogenic alterations that occur within the PTEN/PI3K/AKT pathway in lung cancer. PLoS One. 2017;12(6):e0178865.

128. Sun H, Zhou X, Bao Y, Xiong G, Cui Y, Zhou H. Involvement of miR-4262 in paclitaxel resistance through the regulation of PTEN in non-small cell lung cancer. Open Biol. 2019;9(7):180227.

129. Feng X, Liu H, Zhang Z, Gu Y, Qiu H, He Z. Annexin A2 contributes to cisplatin resistance by activation of JNK-p53 pathway in non-small cell lung cancer cells. J Exp Clin Cancer Res. 2017;36(1):123.

130. Xing Y, Liu Y, Liu T, Meng Q, Lu H, Liu W, et al. TNFAIP8 promotes the proliferation and cisplatin chemoresistance of non-small cell lung cancer through MDM2/p53 pathway. Cell Commun Signaling. 2018;16(1):43.

131. Siegel RL, Miller KD, Jemal A. Cancer statistics, 2017. CA Cancer J Clin. 2017; 67(1):7-30.

132. Zhou HY, Yao XM, Chen XD, Tang JM, Qiao ZG, Wu XY. Mechanism of metformin enhancing the sensitivity of human pancreatic cancer cells to gem-citabine by regulating the PI3K/Akt/mTOR signaling pathway. Eur Rev Med Pharmacol Sci. 2019:23(23):10283-9.

133. Kukcinaviciute E, Jonusiene V, Sasnauskiene A, Dabkeviciene D, Eidenaite E, Laurinavicius A. Significance of Notch and Wnt signaling for chemoresistance of colorectal cancer cells HCT116. J Cell Biochem. 2018; 119(7):5913-20.

134. Yang Y, Ahn YH, Gibbons DL, Zang Y, Lin W, Thilaganathan N, et al. The Notch ligand Jagged2 promotes lung adenocarcinoma metastasis through a miR-200-dependent pathway in mice. J Clin Invest. 2011;121(4):1373-85..

135. Bartůnek P, Králová J, Blendinger G, Dvorák M, Zenke M. GATA-1 and c-myb crosstalk during red blood cell differentiation through GATA-1 binding sites in the c-myb promoter. Oncogene. 2003;22(13):1927-35.

136. Vaish V, Kim J, Shim M. Jagged-2 (JAG2) enhances tumorigenicity and chemoresistance of colorectal cancer cells. Oncotarget. 2017;8(32):53262-75.

137. Mirone G, Perna S, Shukla A, Marfe G. Involvement of Notch-1 in resistance to Regorafenib in Colon Cancer cells. J Cell Physiol. 2016;231(5):1097-105.

138. Zhang $F$, Sun $H$, Zhang S, Yang $X$, Zhang G, Su T. Overexpression of PER3 inhibits self-renewal capability and Chemoresistance of colorectal Cancer stem-like cells via inhibition of Notch and $\beta$-catenin signaling. Oncol Res. 2017;25(5):709-19.

139. Li DD, Zhao CH, Ding HW, Wu Q, Ren TS, Wang J, et al. A novel inhibitor of ADAM17 sensitizes colorectal cancer cells to 5 -fluorouracil by reversing Notch and epithelial-mesenchymal transition in vitro and in vivo. Cell Prolif. 2018;51(5):e12480

140. Kubiliūtè R, Šulskytè I, Daniūnaitè K, Daugelavičius R, Jarmalaitė S. Molecular features of doxorubicin-resistance development in colorectal cancer CX-1 cell line. Medicina (Kaunas, Lithuania). 2016;52(5):298-306.

141. Wu YZ, Lin HY, Zhang Y, Chen WF. miR-200b-3p mitigates oxaliplatin resistance via targeting TUBB3 in colorectal cancer. J Gene Med. 2020;22(7):e3178.

142. Wang M, He SF, Liu LL, Sun XX, Yang F, Ge Q, et al. Potential role of ZEB1 as a DNA repair regulator in colorectal cancer cells revealed by cancerassociated promoter profiling. Oncol Rep. 2017;38(4):1941-8.

143. You M, Yuan S, Shi J, Hou Y. PPARS signaling regulates colorectal cancer. Curr Pharm Des. 2015:21(21):2956-9.

144. Chen L, Zhu Z, Gao W, Jiang Q, Yu J, Fu C. Systemic analysis of different colorectal cancer cell lines and TCGA datasets identified IGF-1R/EGFR-PPARCASPASE axis as important indicator for radiotherapy sensitivity. Gene. 2017; 627:484-90.

145. Tong JL, Zhang CP, Nie F, Xu XT, Zhu MM, Xiao SD, et al. MicroRNA 506 regulates expression of PPAR alpha in hydroxycamptothecin-resistant human colon cancer cells. FEBS Lett. 2011;585(22):3560-8.

146. Wang D, Ning W, Xie D, Guo L, DuBois RN. Peroxisome proliferatoractivated receptor $\delta$ confers resistance to peroxisome proliferator- 
activated receptor $\gamma$-induced apoptosis in colorectal cancer cells. Oncogene. 2012;31(8):1013-23.

147. Zhu MM, Tong JL, Xu Q, Nie F, Xu XT, Xiao SD, et al. Increased JNK1 signaling pathway is responsible for ABCG2-mediated multidrug resistance in human colon cancer. PLoS One. 2012;7(8):e41763.

148. Sui $X$, Kong N, Wang $X$, Fang $Y$, Hu X, Xu Y, et al. JNK confers 5 -fluorouracil resistance in p53-deficient and mutant p53-expressing colon cancer cells by inducing survival autophagy. Sci Rep. 2014;4:4694.

149. Mitra T, Prasad P, Mukherjee P, Chaudhuri SR, Chatterji U, Roy SS. Stemness and chemoresistance are imparted to the OC cells through TGF $\beta 1$ driven EMT. J Cell Biochem. 2018:119(7):5775-87.

150. Colombo PE, Fabbro M, Theillet C, Bibeau F, Rouanet P, Ray-Coquard I. Sensitivity and resistance to treatment in the primary management of epithelial ovarian cancer. Crit Rev Oncol Hematol. 2014;89(2):207-16.

151. Brasseur K, Gévry N, Asselin E. Chemoresistance and targeted therapies in ovarian and endometrial cancers. Oncotarget. 2017;8(3):4008-42.

152. Muñoz-Galván S, Felipe-Abrio B, García-Carrasco M, Domínguez-Piñol J, Suarez-Martinez E, Verdugo-Sivianes EM, et al. New markers for human ovarian cancer that link platinum resistance to the cancer stem cell phenotype and define new therapeutic combinations and diagnostic tools. J Exp Clin Cancer Res. 2019;38(1):234.

153. Rodriguez-Aguayo C, Bayraktar E, Ivan C, Aslan B, Mai J, He G, et al. PTGER3 induces ovary tumorigenesis and confers resistance to cisplatin therapy through up-regulation Ras-MAPK/Erk-ETS1-ELK1/CFTR1 axis. EBioMedicine. 2019;40:290-304.

154. Zhou Y, Zhu Y, Fan X, Zhang C, Wang Y, Zhang L, et al. NID1, a new regulator of EMT required for metastasis and chemoresistance of ovarian cancer cells. Oncotarget. 2017;8(20):33110-21.

155. Kang YS, Seok HJ, Jeong EJ, Kim Y, Yun SJ, Min JK, et al. DUSP1 induces paclitaxel resistance through the regulation of p-glycoprotein expression in human ovarian cancer cells. Biochem Biophys Res Commun. 2016:478(1):403-9.

156. Gu ZW, He YF, Wang WJ, Tian Q, Di W. MiR-1180 from bone marrowderived mesenchymal stem cells induces glycolysis and chemoresistance in ovarian cancer cells by upregulating the Wnt signaling pathway. J Zhejiang Univ Sci B. 2019;20(3):219-37.

157. Fukumoto T, Zhu H, Nacarelli T, Karakashev S, Fatkhutdinov N, Wu S, et al. N(6)-methylation of adenosine of FZD10 mRNA contributes to PARP inhibitor resistance. Cancer Res. 2019;79(11):2812-20.

158. Beretta GL, Corno C, Zaffaroni N, Perego P. Role of FoxO Proteins in Cellular Response to Antitumor Agents. Cancers. 2019;11(1):90.

159. Cai D, lyer A, Felekkis KN, Near Rl, Luo Z, Chernoff J, et al. AND-34/BCAR3, a GDP exchange factor whose overexpression confers antiestrogen resistance, activates Rac, PAK1, and the cyclin D1 promoter. Cancer Res. 2003;63(20): 6802-8

160. Wallez Y, Riedl SJ, Pasquale EB. Association of the breast cancer antiestrogen resistance protein 1 (BCAR1) and BCAR3 scaffolding proteins in cell signaling and antiestrogen resistance. J Biol Chem. 2014;289(15):10431-44.

161. de la Fuente MT, Casanova B, Moyano JV, Garcia-Gila M, Sanz L, GarciaMarco J, et al. Engagement of alpha4beta1 integrin by fibronectin induces in vitro resistance of $B$ chronic lymphocytic leukemia cells to fludarabine. Leukoc Biol. 2002;71(3):495-502.

162. Huang C, Tu Y, Freter CE. Fludarabine-resistance associates with ceramide metabolism and leukemia stem cell development in chronic lymphocytic leukemia. Oncotarget. 2018;9(69):33124-37.

163. Chung IF, Chang SJ, Chen CY, Liu SH, Li CY, Chan CH, et al. YM500v3: a database for small RNA sequencing in human cancer research. Nucleic Acids Res. 2017;45(D1):D925-d31.

164. La Ferlita A, Alaimo S, Veneziano D, Nigita G, Balatti V, Croce CM, et al. Identification of tRNA-derived ncRNAs in TCGA and NCI-60 panel cell lines and development of the public database tRFexplorer. Database. 2019;2019: baz115.

165. Pliatsika V, Loher P, Magee R, Telonis AG, Londin E, Shigematsu M, et al. MINTbase v2.0: a comprehensive database for tRNA-derived fragments that includes nuclear and mitochondrial fragments from all the Cancer genome atlas projects. Nucleic Acids Res. 2018;46(D1):D152-d9.

\section{Publisher's Note}

Springer Nature remains neutral with regard to jurisdictional claims in published maps and institutional affiliations.

Ready to submit your research? Choose BMC and benefit from:

- fast, convenient online submission

- thorough peer review by experienced researchers in your field

- rapid publication on acceptance

- support for research data, including large and complex data types

- gold Open Access which fosters wider collaboration and increased citations

- maximum visibility for your research: over $100 \mathrm{M}$ website views per year

At BMC, research is always in progress.

Learn more biomedcentral.com/submissions 